\title{
Spikes and Membrane Potential Oscillations in Hair Cells Generate Periodic Afferent Activity in the Frog Sacculus
}

\author{
Mark A. Rutherford and William M. Roberts \\ Institute of Neuroscience, Department of Biology, University of Oregon, Eugene, Oregon 97403
}

To look for membrane potential oscillations that may contribute to sensory coding or amplification in the ear, we made whole-cell and perforated-patch recordings from hair cells and postsynaptic afferent neurites in the explanted frog sacculus, with mechanoelectrical transduction (MET) blocked. Small depolarizing holding currents, which may serve to replace the in vivo resting MET current, evoked all-or-none calcium spikes (39-75 mV amplitude) in 37\% of hair cells tested, and continuous membrane potential oscillations (14-28 $\mathrm{mV} ; 15-130 \mathrm{~Hz}$ ) in an additional 14\% of cells. Spiking hair cells were on average taller and thinner than nonspiking hair cells, and had smaller outward currents through delayed rectifier channels $\left(I_{\mathrm{KV}}\right)$ and noninactivating calcium-activated potassium channels $\left(I_{\mathrm{BK}, \mathrm{steady}}\right)$, and larger inward rectifier currents $\left(I_{\mathrm{K} 1}\right)$. Some spiking hair cells fired only a brief train at the onset of a current step, but others could sustain repetitive firing $(3-70 \mathrm{~Hz})$. Partial blockade of $I_{\mathrm{BK}}$ changed the amplitude and frequency of oscillations and spikes, and converted some nonspiking cells into spiking cells. Oscillatory hair cells preferentially amplified sinusoidal stimuli at frequencies near their natural oscillation frequency. Postsynaptic recordings revealed regularly timed bursts of EPSPs in some afferent neurites. EPSP bursts were able to trigger afferent spikes, which may be initiated at the sodium channel cluster located adjacent to the afferent axon's most peripheral myelin segment. These results show that some frog saccular hair cells can generate spontaneous rhythmic activity that may drive periodic background activity in afferent axons.

\section{Introduction}

As a detector of seismic waves and airborne sounds in the 5-200 $\mathrm{Hz}$ frequency range (Eatock et al., 1987; Yu et al., 1991), the frog sacculus contains mechanosensory hair cells specialized for sensitivity to these low-frequency stimuli. One specialization, electrical tuning, amplifies membrane potential changes at frequencies near the hair cell's "resonance" frequency and causes transient oscillatory responses to current steps (Ashmore, 1983; Lewis and Hudspeth, 1983). The mechanism of electrical tuning in the frog sacculus was previously studied using whole-cell voltage clamp of isolated (i.e., enzyme treated and mechanically dissociated) hair cells (Hudspeth and Lewis, 1988a,b) and found to be similar to electrical tuning of auditory hair cells in other nonmammalian vertebrate species (reviewed by Fettiplace and Fuchs, 1999). These results support a model in which sensory inputs pass through several stages of "graded" signal processing, including mechanoelectrical transduction (MET), electrical resonance, and specialized synaptic transmission (Rutherford and Roberts, 2006), before a nerve impulse is generated in the afferent neurite (reviewed by Roberts and Rutherford, 2008).

Some of the data that support this model are inconsistent with in vivo frequency selectivity and experiments using hair cells in

\footnotetext{
Received April 14, 2009; revised June 25, 2009; accepted July 6, 2009.

This work was supported by National Institutes of Health Grant R01 NS27142 to W.M.R. We thank Shawn Lockery and the Institute of Neuroscience Cellular Physiology discussion group for comments on figures and Mike Wehr for comments on this manuscript.

Correspondence should be addressed to Dr. William M. Roberts, Institute of Neuroscience, 1254, University of Oregon, Eugene, 0R 97403. E-mail: billr@uoregon.edu.

D0I:10.1523/JNEUROSCI.1798-09.2009

Copyright $\odot 2009$ Society for Neuroscience $\quad$ 0270-6474/09/2910025-13\$15.00/0
}

more intact preparations. For example, frog saccular hair cells isolated using papain have sharply tuned resonances at frequencies $>100 \mathrm{~Hz}$, but the sacculus is broadly tuned and most sensitive at $50 \mathrm{~Hz}$. This discrepancy has been explained by the effects of this enzyme on $I_{\mathrm{BK}}, I_{\mathrm{KV}}$, and the voltage-gated $\mathrm{Ca}^{2+}$ current $\left(I_{\mathrm{Ca}}\right)$ (Armstrong and Roberts, 1998, 2001). Isolation procedures using other enzymes may have less severe effects on hair cell properties (Catacuzzeno et al., 2003a,b), but there are no reports of any isolation procedure that preserves the capacity of frog saccular hair cells to generate all-or-none spikes, which have been observed only in more intact preparations using sharp electrodes (Hudspeth and Corey, 1977; Ashmore, 1983) or patch pipettes (Armstrong and Roberts, 1998). Spikes and spontaneous oscillations have been reported for low-frequency hair cells isolated with papain from the sacculi of fish (Sugihara and Furukawa, 1989; Steinacker and Romero, 1992) and the cochleae of alligators (Fuchs and Evans, 1988; Eatock et al., 1993) and chicks (Fuchs et al., 1988).

Some experiments on isolated frog saccular hair cells have shown spontaneous membrane potential oscillations and other instabilities (Ospeck et al., 2001; Catacuzzeno et al., 2004; Jørgensen and Kroese, 2005). Spontaneous electrical activity in hair cells may be involved in bidirectional feedback interactions with active hair bundle motility (Denk and Webb, 1992; Martin et al., 2003) to maximize sensitivity to small sensory signals (Eguíluz et al., 2000). It could also influence both the background spike pattern (Manley, 1979; Crawford and Fettiplace, 1980) and the precise spike timing in afferent axons from the frog sacculus (Koyama et al., 1982; Christensen-Dalsgaard and Narins, 1993).

We studied nonisolated frog saccular hair cells, and show that some generate spontaneous and evoked spikes and oscil- 
lations. We describe the ionic currents associated with these phenomena, and show that spontaneous hair cell activity can cause transmitter release that triggers impulses in afferent neurites.

\section{Materials and Methods}

Experimental preparation. Rana pipiens (Niles Biological) were maintained at $17^{\circ} \mathrm{C}$ and killed (double pithed, then decapitated) before dissection in accordance with the regulations of the Institutional Animal Care and Use Committee of the University of Oregon. All experiments were performed in a temperature-controlled room at $20-22^{\circ} \mathrm{C}$ and were completed within $4 \mathrm{~h}$. Approximately 100 frogs were used in this study. The sacculus was isolated and the otolithic membrane removed under a dissecting microscope before transferring the tissue to a rectangular well cut into silicone elastomere (Sylgard 184; Dow Corning) on a microscope slide. The tissue was secured by sliding the edges of the epithelium under steel pins stuck horizontally into the Sylgard, and the sensory epithelium was furrowed to the minimum depth required to expose nerve fibers and the basolateral surfaces of hair cells. Furrowing began by making a small tear in the apical surface of the macula with a piece of dog hair $(0.5 \mathrm{~cm}$ long) glued to a stick (Armstrong and Roberts, 1998; Rutherford and Roberts, 2006). The chamber was then transferred to a fixed-stage upright microscope and viewed under differential interference contrast (DIC) optics $(63 \times$ objective with $10 \times$ eyepieces), and the furrow was extended using fine-tipped glass probes mounted on micromanipulators. A wide-tipped (5-20 $\mu \mathrm{m})$ capillary glass suction pipette was then used to gently clear away dead cells and debris. A suitable recording site was located on hair cell basolateral membranes, or on a submicron diameter nonmyelinated neurite 5-20 $\mu \mathrm{m}$ from the closest synaptic terminal.

Electrophysiology. Dissection and electrical recording were performed in extracellular saline solution (normal artificial perilymph) that contained the following (in $\mathrm{mm}$ ): $112 \mathrm{Na}^{+}, 2 \mathrm{~K}^{+}, 1.8 \mathrm{Ca}^{2+}, 119 \mathrm{Cl}^{-}, 5$ HEPES, and 3 D-glucose. High- $\mathrm{K}^{+}$artificial perilymph $\left(40 \mathrm{~mm} \mathrm{~K}^{+}\right)$was made by equimolar substitution for $\mathrm{Na}^{+}$. The concentration of $\mathrm{Ca}^{2+}$ $(1.8 \mathrm{~mm})$ in the extracellular solution greatly diminishes resting MET (Corey and Hudspeth, 1983; Farris et al., 2006), which in 21 of 49 hair cell recordings and all postsynaptic afferent recordings was additionally blocked by adding $100 \mu \mathrm{M}$ amiloride (Jørgensen and Ohmori, 1988). Recording pipettes were filled with intracellular solution that contained the following (in mM): $104 \mathrm{~K}^{+}, 8 \mathrm{Na}^{+}, 2 \mathrm{Mg}^{2+}, 0.274 \mathrm{Ca}^{2+}, 109 \mathrm{Cl}^{-}$or aspartate, 1 EGTA, 10 HEPES, 5 glutathione, 3 ATP, and 1 GTP. For perforated-patch recording, we used filament-glass pipettes and dipped the back end in normal intracellular solution for 5-10 s to draw a small amount of fluid into the tip before filling with intracellular solution that contained both a lipophilic polyene (solubilized amphotericin B, 500$1500 \mu \mathrm{g} / \mathrm{ml}$ ) to create transmembrane channels and a membraneimpermeant fluorescent marker (3000 MW fluorescein-dextran, $30 \mu \mathrm{g} /$ $\mathrm{ml}$, Invitrogen) to monitor patch rupture. All solutions were titrated to approximately pH 7.25 and $220 \mathrm{mOsm}$. Except as noted, all reagents were purchased from Sigma.

Data were acquired using an EPC10 intracellular amplifier (HEKA Elektronik), low-pass filtered ( $7 \mathrm{kHz}$ cutoff), and digitized ( 20 or $40 \mathrm{kHz}$ sample rate). Pipettes for intracellular recording were pulled from borosilicate filament-glass on a model P-2000 electrode puller (Sutter Instruments). To minimize access resistance, pipettes were pulled to taper steeply at the tip and subsequently shaped by heating the tip while applying pressure to the lumen (Goodman and Lockery, 2000).

The pipette voltage offset was adjusted to null the current at $-6 \mathrm{mV}$ or $-13 \mathrm{mV}$ (the calculated liquid junction potential between the intracellular and extracellular solutions for potassium chloride or potassium aspartate, respectively) before advancing the pipette into contact with the hair cell or neurite. Hair cell recordings had access resistances generally below $15 \mathrm{M} \Omega$ for whole-cell (ruptured-patch) and below $20 \mathrm{M} \Omega$ for perforated patch. The current-clamp traces displayed have not been corrected for errors due to series resistance (12.9 $\pm 1.0 \mathrm{M} \Omega$, mean \pm SEM). For the voltage-clamp $I-V$ curves (see Fig. 6; supplemental Figs. S2, S3, available at www.jneurosci.org as supplemental material) the command potential was corrected for errors due to series resistance based on the net current in each $0.5 \mathrm{~ms}$ time window. The fits in Figure 5 are for voltageclamp commands to -120 and $-30 \mathrm{mV}$, not corrected for errors due to series resistance. We did not apply active $R_{\mathrm{s}}$ compensation in the present study. For voltage-clamp recordings, the average $R_{\mathrm{s}}$ (mean \pm SEM) was $12.6 \pm 1.2 \mathrm{M} \Omega$ for all cells, and this mean was not significantly different from the mean $R_{\mathrm{s}}$ for spiking $(13.3 \pm 0.9 \mathrm{M} \Omega, n=10, p=0.74)$, oscillating (11.4 $\pm 1.5 \mathrm{M} \Omega, n=4, p=0.70)$, or nonoscillating $(12.5 \pm$ $0.6, n=13, p=0.97)$ hair cells.

Successful recordings from afferent neurons were identified by the ability to elicit spikes upon current injection, and verified by filling the process with dye from the recording electrode. Spikes in afferent neurons were reversibly abolished by $1 \mu \mathrm{M}$ tetrodotoxin (TTX, Sigma), and synaptic events were attenuated by $75 \%$ by $10 \mu \mathrm{M}$ 6-cyano-7nitroquinoxaline-2,3-dione (CNQX, Sigma), an AMPA-type glutamate receptor antagonist that blocks hair cell afferent synapses (Glowatzki and Fuchs, 2002; Keen and Hudspeth, 2006). Diffusion barriers between the bath and the synaptic clefts in the semi-intact epithelium may have been responsible for the incomplete block by CNQX, as evidenced by the prolonged onset and recovery times (minutes).

Fitting of currents. We used the known activation time course of each of the six major voltage-gated and calcium-gated conductances to separate the total currents evoked by command steps from a holding potential of $-70 \mathrm{mV}$ to $-30 \mathrm{mV}$, and from $-70 \mathrm{mV}$ to $-120 \mathrm{mV}$, into the sum of individual components:

$$
\begin{aligned}
I_{-30}(t)=F(t) *\left\{I_{\mathrm{Ca}}(t)+I_{\mathrm{KV}}(t)+I_{\mathrm{BK}, \text { transient }}(t)\right. & \left.+I_{\mathrm{BK}, \text { steady }}(t)\right\}, \\
I_{-120}(t) & =F(t) *\left\{I_{\mathrm{K} 1}(t)+I_{\mathrm{h}}(t)\right\},
\end{aligned}
$$

where $I_{-30}(t)$ and $I_{-120}(t)$ are the leak-subtracted data, $I_{\mathrm{h}}$ is the hyperpolarization-activated $\mathrm{K}^{+} / \mathrm{Na}^{+}$current, " ” is the convolution operation, and $F(t)$ is the impulse response of the low-pass filter associated with the recording. $F(t)$ resulted primarily from the electrode resistance and cell capacitance, but also included the $7 \mathrm{kHz}$ anti-aliasing filter, which further smoothed and delayed the recorded currents. For $F(t)$, we used the transient response to a small (2-4 $\mathrm{mV}$ amplitude) depolarizing voltage command from $-70 \mathrm{mV}$, normalized to have area $=1$. The response to the small command step was also used for leak subtraction and to determine the charging time constant, $\tau_{\mathrm{RC}}$. To account for the delay in applying voltage-clamp commands through the electrode series resistance, the command was also assumed to be delayed by $0.6 \tau_{\mathrm{RC}}$.

We did not include the A-type $\mathrm{K}^{+}$current in our analysis because, if present, it is almost completely inactivated at $-70 \mathrm{mV}$ (Catacuzzeno et al., 2003b), or the small-conductance $\mathrm{Ca}^{2+}$-activated $\mathrm{K}^{+}$current $\left(I_{\mathrm{SK}}\right)$, because it is small $(<70 \mathrm{pA})$ for step commands from $-70 \mathrm{mV}$ to -30 $\mathrm{mV}$ and is present in only some frog saccular hair cells (Chabbert, 1997). If present, $I_{\mathrm{SK}}$ would be included in $I_{\mathrm{KV}}$ because the two currents have similar activation kinetics.

We used Hodgkin-Huxley models to describe $I_{\mathrm{Ca}}, I_{\mathrm{KV}}, I_{\mathrm{K} 1}$, and $I_{\mathrm{h}}$ (Armstrong and Roberts, 1998, 2001; Catacuzzeno et al., 2003b):

$$
\begin{gathered}
I_{\mathrm{Ca}}(t)=\bar{I}_{\mathrm{Ca}} \cdot\left(1-e^{-t / \tau_{\mathrm{Ca}}}\right)^{3}, \\
I_{\mathrm{KV}}(t)=\bar{I}_{\mathrm{KV}} \cdot\left(1-e^{-t / \tau_{\mathrm{KV}}}\right)^{2}, \\
I_{\mathrm{K} 1}(t)=\bar{I}_{\mathrm{K} 1} \cdot\left(1-e^{-t / \tau_{\mathrm{K} 1}}\right), \\
I_{\mathrm{h}}(t)=\bar{I}_{\mathrm{h}} \cdot\left(1-e^{-t / \tau_{\mathrm{h}}}\right),
\end{gathered}
$$

where $\tau_{\mathrm{Ca}}=110 \mu \mathrm{s}, \tau_{\mathrm{K} 1}=1 \mathrm{~ms}, \tau_{\mathrm{h}}=100 \mathrm{~ms}$, and $\bar{I}_{\mathrm{Ca}}, \bar{I}_{\mathrm{KV}}, \bar{I}_{\mathrm{K} 1}$, and $\bar{I}_{\mathrm{h}}$ were the fitted asymptotes of the currents at $t=\infty$. We found it necessary to fit $\tau_{\mathrm{KV}}$ separately for each cell, with the constraint that $\tau_{\mathrm{KV}}>5 \mathrm{~ms}$.

We modeled separate populations of inactivating $\left(I_{\mathrm{BK} \text {,transient }}\right)$ and noninactivating $\left(I_{\mathrm{BK}, \text { steady }}\right)$ calcium-activated potassium channels (Armstrong and Roberts, 2001). $I_{\mathrm{BK} \text {,steady }}$ was modeled using a kinetic scheme with three closed states $\left(C_{0}, C_{1}, C_{2}\right)$ and two open states $\left(O_{2}, O_{3}\right)$ (Hudspeth and Lewis, 1988b; Catacuzzeno et al., 2004): 


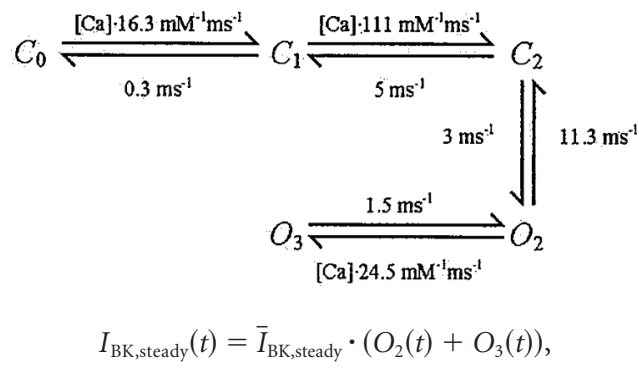

where $O_{2}(t)+O_{3}(t)$ is the probability that a BK channel is open and $\bar{I}_{\mathrm{BK} \text {,steady }}$ is the current that would flow if all noninactivating BK channels were open. We used the same kinetic constants as Hudspeth and Lewis (1988b), except that we increased the rate constant $\mathrm{C}_{2} \rightarrow \mathrm{O}_{2}$ from 1.0 $\mathrm{ms}^{-1}$ to $3.0 \mathrm{~ms}^{-1}$ to obtain sufficiently rapid BK channel activation to fit the data. In keeping with the model, we assumed that free $\mathrm{Ca}^{2+}$ accumulated in proportion to $I_{\mathrm{Ca}}$ and decayed exponentially:

$$
\begin{aligned}
& {[\mathrm{Ca}](t)=\rho \cdot I_{\mathrm{Ca}}(t) * E(t),} \\
& E(t)=k \cdot e^{-k t} \quad(t>0),
\end{aligned}
$$

where $k=2.8 \mathrm{~ms}^{-1}$ and $\rho$ was a fitted parameter that specifies the coupling between $\mathrm{Ca}^{2+}$ channels and BK channels (units: millimolar per picoampere).

We modeled $I_{\mathrm{BK}, \text { transient }}$ as a separate population of channels with three closed states $\left(C_{0}^{\prime}, C_{1}^{\prime}, C_{2}^{\prime}\right)$, two open states $\left(O_{2}^{\prime}, O_{3}^{\prime}\right)$, and one inactivated state:

$$
I_{\mathrm{BK}, \text { transient }}(t)=\bar{I}_{\mathrm{BK}, \text { transient }} \cdot\left(O_{2}^{\prime}(t)+O_{3}^{\prime}(t)\right) .
$$

We used the same activation gating scheme as for $I_{\mathrm{BK} \text {,steady }}$, and assumed that inactivation occurred only after the channel opened, with a rate constant of $3.3 \mathrm{~ms}^{-1}$ from either open state. This produced a peak open probability of $\sim 0.3$, consistent with the increased $I_{\mathrm{BK}}$ following application of papain, and a macroscopic inactivation time constant of 1-2 ms (Armstrong and Roberts, 2001).

We used a combination of linear least-squares fitting and a trial-anderror search algorithm to find the values of $\bar{I}_{\mathrm{Ca}}, \bar{I}_{\mathrm{KV}}, \bar{I}_{\mathrm{BK} \text {,transient, }} \bar{I}_{\mathrm{BK} \text {,steady' }}$ $\bar{I}_{\mathrm{K} 1}, \bar{I}_{\mathrm{h}}, \rho$, and $\tau_{\mathrm{KV}}$ that minimized the mean squared error. The procedure always converged to the same solution in $<1000$ iterations. The reported values of $I_{\mathrm{Ca}}, I_{\mathrm{KV}}, I_{\mathrm{BK}, \text { steady }}, I_{\mathrm{K} 1}$, and $I_{\mathrm{h}}$ are the fitted currents at the end of the voltage-clamp step. The reported value of $I_{\mathrm{BK} \text {,transient }}$ is the maximum transient BK current during the step.

Confocal imaging. For cytoplasmic nerve fill (see Fig. 8 A), the VIIIth cranial nerve was sectioned close to the brainstem, and the isolated sacculus (not furrowed) was transferred to a Petri dish containing artificial perilymph $+100 \mu \mathrm{m}$ amiloride. The cut end of the nerve was placed in a small well formed by a petroleum jelly dam and incubated for $12 \mathrm{~h}$ at $4^{\circ} \mathrm{C}$ in $30 \mathrm{mg} / \mathrm{ml}$ fluorescein-dextran (3000 MW; Invitrogen) dissolved in intracellular saline. In some experiments, $5 \mu \mathrm{M}$ FM1-43 (Invitrogen) was included in the artificial perilymph, followed by a wash in perilymph with $100 \mu \mathrm{M} \mathrm{Cd}{ }^{2+}$ (see Fig. $8 A$, bottom inset). For viewing on the confocal microscope (Bio$\mathrm{Rad})$, the sacculus was mounted in artificial perilymph $+100 \mu \mathrm{M}$ amiloride under a coverslip on a microscope slide.

For immunochemistry afferent neurites were labeled with a monoclonal neurofilament antibody (neurofilament-associated antigen 3A10, Developmental Studies Hybridoma Bank) or a pan-specific monoclonal voltage-gated sodium channel antibody (anti-pan- $\mathrm{Na}^{+}$channel, mouse IgG1, Sigma) (Rasband et al., 1999). The tissue was dissected and isolated in artificial perilymph $+100 \mu \mathrm{m}$ amiloride, then fixed for $45 \mathrm{~min}$ at room temperature in artificial perilymph $+4 \%$ paraformaldehyde. Following a wash at room temperature $(3 \times 15 \mathrm{~min})$ in PBS (in mM: $137 \mathrm{NaCl}, 2.7$ $\mathrm{KCl}$, and 20 phosphate buffer), the tissue was permeabilized for $1 \mathrm{~h}$ at room temperature in PBDT (PBS with 1\% BSA, 1\% DMSO, $0.1 \%$ Triton, and $2.5 \%$ goat serum), rocked overnight at $4^{\circ} \mathrm{C}$ in primary antibody (1:2000 in PBDT), washed at room temperature $(3 \times 15 \mathrm{~min}$ on a rocker $)$ in PBDT, and incubated in secondary antibody (1:200 in PBDT) on a rocker for $1 \mathrm{~h}$ at room temperature. The tissue was rinsed once more on a rocker $(3 \times 15 \mathrm{~min}$ in $\mathrm{PBDT})$ at room temperature before being mounted under a coverslip in FluoroGuard (Bio-Rad). Control sections with primary antibody omitted were processed in parallel and in no cases did the controls fluoresce above background levels.

Data analysis. Hair cell spike or oscillation amplitude and frequency were calculated at different levels of holding current between -50 and $+300 \mathrm{pA}$ (see Figs. 2, 3, 5E, F). The holding current was held constant for several seconds, and the maximum (peak-to-trough) voltage excursion in the data record was measured, excluding the initial $100 \mathrm{~ms}$. The peakpower frequency of the data sample was determined from the power spectrum, computed by taking the Fourier transform of the non-circular autocorrelation function of the data, using the FFT and CORRELATE operations in IGOR software (Wavemetrics).

In hair cells that generated spikes at holding current $=0 \mathrm{pA}$, resting potential was measured, when possible, as the interspike baseline. For all other hair cells, including those that generated spontaneous oscillations, resting potential was measured by time averaging a representative data sample obtained with a command of 0 pA. Some hair cells $(24 \%)$ displayed a form of membrane potential instability at holding currents between $+50 \mathrm{pA}$ and $-50 \mathrm{pA}$ in which the membrane potential flipped spontaneously between two states (Jørgensen and Kroese, 2005). In these cells, resting potential and all other measurements were made using the state with the greatest dwell time. These transitions between two relatively hyperpolarized membrane potentials were excluded from analyses of amplitude and frequency for spiking, oscillating, and nonoscillating cells (i.e., their amplitudes were not measured for consideration as a spike or oscillation, nor were data segments containing such transitions included in the analysis of the power spectra).

In one series of experiments we used the length:apical diameter ratio (see Fig. 3F, G) as a measure of hair cell morphology (Chabbert, 1997). When allowed by the spatial relationship between hair cells on the edge of the furrowed epithelium and the microscope objective, we estimated the apical diameter and the distance from apical plate to basal pole, using an eyepiece micrometer and DIC optics (see Fig. $8 C$ ) before the recording. To aid in this measurement, a suction pipette was used to gently pull on the neighboring epithelium to cause the target hair cell to protrude horizontally in the $x-y$ plane of the microscope.

EPSC waveforms (low-pass filtered at $7 \mathrm{kHz}$ ) (see Figs. 9, 10) were analyzed to determine event amplitudes and occurrence times using the Mini Analysis Program (Synaptosoft), and verified by eye. Waveforms with more than one inward current peak were considered to consist of multiple events, and the time of each peak was recorded as a time of occurrence. Event amplitude was measured as the difference between the current measured at the peak and at the event onset. For the autocorrelation of a hair cell oscillation or afferent EPSC train (supplemental Fig. $\mathrm{S} 1 \mathrm{~B}, E$, available at www.jneurosci.org as supplemental material), the noncircular autocorrelation function was computed using the CORRELATE operation in IGOR software.

Statistical averages are presented as mean \pm SEM. Comparisons were made with two-tailed $t$ tests assuming unequal variances.

\section{Results}

The data in this study were obtained from 49 hair cell recordings (35 ruptured patch, 14 perforated patch) and 22 recordings from postsynaptic afferent neurites, all from the isolated frog sacculus in which both the apical and basolateral hair cell surfaces were exposed to artificial perilymph. The high $\mathrm{Ca}^{2+}$ concentration in perilymph $(1.8 \mathrm{~mm})$ compared with endolymph $(50-100 \mu \mathrm{M})$ inhibits the resting excitatory MET current, thereby hyperpolarizing hair cells relative to the in vivo resting potential (Holton and Hudspeth, 1986; Eatock et al., 1987; Shepherd and Corey, 1994; Vollrath and Eatock, 2003; Farris et al., 2006). Averaged across all hair cells, the resting potential was $-63.9 \pm 1.9 \mathrm{mV}(n=28)$ with no additional blockade of MET, and $-73.2 \pm 3.0 \mathrm{mV}(n=21)$ in another group of hair cells with $100 \mu \mathrm{M}$ amiloride in the bath to block residual MET. No other effects of amiloride were noted; therefore data from both groups have been combined. Spikes, oscillations, and nonoscillating resting potentials were observed in 
both whole-cell and perforated-patch recordings, as well as with and without amiloride. All recordings from afferent neurites were made in the presence of $100 \mu \mathrm{M}$ amiloride.

\section{Hair cell spikes and oscillations at rest and in response to depolarizing holding currents}

Hair cells exhibited several types of spontaneous activity (under current clamp at $I=0)$ in normal artificial perilymph. In addition to cells with relatively stable resting potentials (Fig. 1C), we observed spikes (Fig. 1A), oscillations (Fig. 1B), and membrane potential bistability [rapid transitions between a stable hyperpolarized level and a depolarized level around which oscillations occurred (Fig. 1D), or between two relatively hyperpolarized membrane potentials (Jørgensen and Kroese, 2005)]. Spikes were uniform in size and shape within a given hair cell, with occasional failures to reach threshold (Fig. $1 \mathrm{~A}$ ), indicating that they are all-ornone events. Spike waveforms varied between cells, but typically had sharp peaks separated by a slower voltage ramp during the interspike interval. Unlike spikes, oscillations were not all-or-none events with sharp peaks, but instead were sinusoidal with amplitudes that fluctuated on a timescale of hundreds of milliseconds (Fig. $1 B$ ). Spikes and oscillations coexisted in some hair cells (Fig. 1D).

Depolarizing holding currents modulated the amplitude and increased the frequency of both spikes (Fig. $2 A$ ) and oscillations (Fig. $2 B$ ), and initiated spiking or oscillation in some hair cells that did not spike or oscillate at the resting (zero-current) potential. Spikes and oscillations were distinct from the transient responses following current-clamp steps, which have been studied previously in this preparation (Armstrong and Roberts, 1998). For example, in their Figure 2, Armstrong and Roberts (1998) show damped sinusoidal waveforms $(B, D)$ or waveforms that first decay in amplitude before growing again $(C)$ during the first $100 \mathrm{~ms}$ following a current step. In the present study, we observed spikes and oscillations that occur at $I=0$ and during prolonged depolarizations (e.g., Figs. 1, 2; and see Fig. 6, right panels).

By measuring the largest spike, oscillation, or small membrane potential fluctuation observed over a range of holding currents (2-10 s duration, excluding the transient response during the initial $100 \mathrm{~ms}$ ), we were able to classify hair cells into three groups (Fig. 3E). Forty-nine percent (24/49) had only small membrane potential fluctuations $(\leq 7 \mathrm{mV})$ and were categorized as "nonoscillating"; 14\% (7/49) produced maximum oscillations of 14-28 mV and were classified as "oscillating"; and 37\% (18/ 49) produced large (39-75 $\mathrm{mV}$ ) voltage waveforms at some holding currents, and were classified as "spiking." We note that $44 \%$ of the spiking hair cells also produced smaller oscillations (e.g., supplemental Figs. S2A, S3A, right panels, available at www. jneurosci.org as supplemental material). In our dataset, the distinction between oscillations and spikes could be based solely on amplitude because spikes always exceeded $39 \mathrm{mV}$, whereas oscillations were always $<30 \mathrm{mV}$. Given our limited sample size, and the highly variable amplitudes of the membrane potential oscillations

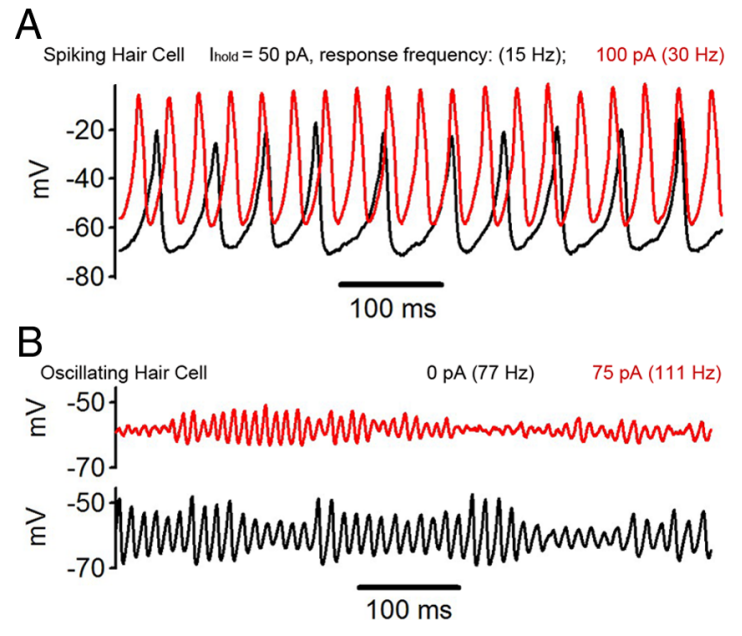

Figure 2. Holding current modulates spikes and oscillations. Each panel shows two current-clamp recordings (red, black) from one cell, with holding current and spike or oscillation frequency shown in the corresponding color. $\boldsymbol{A}$, Depolarization increased the spike rate and reduced timing variability. $\boldsymbol{B}$, Depolarization increased oscillation frequency and decreased the amplitude.

that we observed, we note that the operational definition of spikes and oscillations based solely on amplitude is somewhat arbitrary.

Another distinguishing characteristic of spikes was their clear threshold. As the depolarizing holding current was increased, spiking began abruptly, with the largest spike amplitudes for the smallest holding currents that evoked spikes and slightly smaller spikes during larger depolarizations (Fig. $3 A$ ). In contrast, oscillation amplitudes grew with increasing depolarization, attained a maximum for holding currents between 25 and 150 pA (Fig. 3C), and declined with further depolarization.

Half (9/18) of the spiking hair cells were capable of sustained repetitive firing (e.g., Figs. $1 A, 2 A$; see Fig. $3 A, B$ for summary of amplitudes and frequencies for all 9 cells). Most of these were located in the outer three rows of the saccular macula (supplemental Figure S5A, available at www.jneurosci.org as supplemen- 

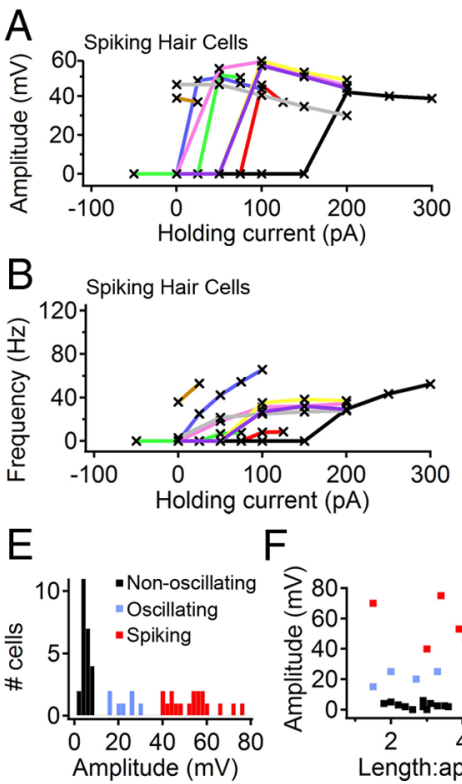

$\mathrm{F}$
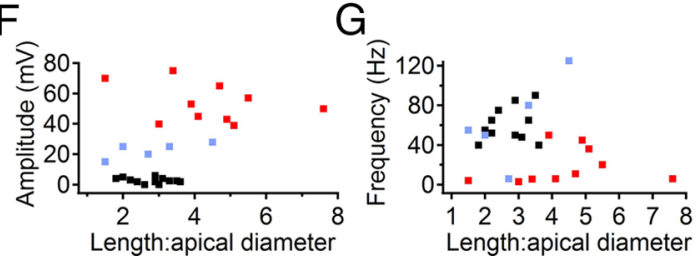

Figure 3. Spike or oscillation amplitude and frequency as a function of holding current, and in relation to cell morphology. $A$, Spike amplitudes at different holding levels for nine hair cells that fired repetitive spike trains. The abrupt appearance of full-size spikes with increased holding current reveals their all-or-none character. $\boldsymbol{B}$, Spike frequencies for the same cells as in $\boldsymbol{A}$. $\boldsymbol{C}$, Maximum oscillation amplitudes at different holding levels in seven nonspiking hair cells. $\boldsymbol{D}, 0$ scillation frequencies for the same cells as in $\boldsymbol{C}$. Different colored lines in $\boldsymbol{A}$ and $\boldsymbol{B}$ and in $\boldsymbol{C}$ and $\boldsymbol{D}$ are for corresponding cells. $\boldsymbol{E}$, Distribution of maximum amplitudes of voltage fluctuations observed in 49 hair cells: spiking (red), oscillating (blue), and nonoscillating (black). $\boldsymbol{F}$, Positive relationship between hair cell length:apical diameter ratio and maximum amplitude. $\mathbf{G}$, Negative relationship between length:apical diameter ratio and peak-power frequency at the holding current that produced the maximum amplitude. Markers in $\boldsymbol{F}$ and $\boldsymbol{G}$ are colored as in $\boldsymbol{E}$.
Within the central field of the saccular macula (i.e., excluding the outer $3-4$ rows that comprise predominantly tall, thin hair cells), spiking hair cells were on average taller and thinner than the others and sometimes had peanut-shaped profiles, while nonspiking hair cells were typically more cylindrical. We quantified these morphological differences by measuring the ratio of cell length to apical diameter before recording from each of 28 hair cells from the central field. Cells were selected based on accessibility for recording, without preference for specific morphology. The mean ratios were significantly larger for spiking hair cells $(4.4 \pm 0.52, n=10)$ than for the others $(2.7 \pm 0.18, n=18$, $p=0.013)$, and did not differ significantly between oscillating $(2.8 \pm 0.52, n=5)$ and nonoscillating $(2.7 \pm 0.18, n=18$, $p=0.90$ ) hair cells. Overall the ratios of length to apical diameter (mean, $3.3 \pm$ 0.26 ; range, $1.5-7.6$ ) were $30-60 \%$ greater than those reported previously for papaintreated and dissociated frog saccular hair cells (Holt and Eatock, 1995), and closer to those reported for other methods of isolation or for nondissociated cells (Chabbert, 1997). Tall and extremely thin hair cells with length to apical diameter tal material), where nearly all (7/8) of the spiking hair cells fired repetitively. In contrast, only 2 of 10 more centrally located hair cells could sustain repetitive firing. We determined the repetitive firing rate from the power spectrum of the membrane potential. Six cells had spike rates that increased to a maximum of $7-10 \mathrm{~Hz}$ $(n=2)$ or $25-40 \mathrm{~Hz}(n=4)$ over a narrow range of depolarizing currents. The other three fired repetitively at higher frequencies $(>50 \mathrm{~Hz})$ and did not reach a maximum firing rate for the largest currents tested.

All but one of the repetitively spiking hair cells (8/9) were active for less than or equal to $+100 \mathrm{pA}$ (Fig. $3 A, B$ ), with spike rates that decreased only slightly over several seconds of depolarizing current, suggesting that they may fire spikes in vivo when depolarized by the resting MET current. Five of these were active for less than or equal to $+50 \mathrm{pA}$ (e.g., Fig. $2 \mathrm{~A}$ ), and two fired repetitively at $I=0$.

Among the nine spiking hair cells that did not generate persistent repetitive activity at any holding current, and therefore did not have a well defined firing rate, five fired irregular lowfrequency spikes at zero current, and four required depolarization to elicit a train of spikes that adapted over seconds (e.g., see Fig. $6 A$, right; supplemental Figs. S2 A, S3A, right panels, available at www.jneurosci.org as supplemental material).

Oscillation frequency, measured as the peak of the power spectrum (see Materials and Methods) was typically $<15 \mathrm{~Hz}$ at zero holding current and reached a plateau between 45 and $70 \mathrm{~Hz}$ for holding currents greater than $+50 \mathrm{pA}$ (Fig. $3 D$ ). Data from five of seven oscillating hair cells were consistent with this pattern. Although oscillations showed great variability in amplitude, the oscillation frequency in response to a particular holding current remained relatively constant over many cycles (supplemental Fig. S1 $A-C$, available at www.jneurosci.org as supplemental material). ratios of 10-20 were observed in the central and peripheral fields of the macula but attempts to record from them were unsuccessful. Despite the differences in length:apical diameter ratio between spiking and nonspiking cells (Fig. $3 F, G$ ), there were no significant differences in $C_{\mathrm{m}}$ between the three classes of hair cells (spiking, $12.9 \pm 1.0 \mathrm{pF}, n=10$; oscillating, $14.5 \pm 1.7 \mathrm{pF}, n=4$; nonoscillating, $14.1 \pm 0.72 \mathrm{pF}, n=12$ ).

\section{Hair cell responses to sinusoidal current stimulation}

To test the frequency selectivity of frog saccular hair cells, a sinusoidal current stimulus was applied, with frequency swept over the range of vibratory sensitivity for the frog sacculus. Spiking hair cells fired multiple spikes per cycle at low frequencies, with fewer spikes per cycle and skipped cycles appearing as the frequency increased, until firing stopped above some frequency that varied among cells (Fig. 4A,B). Oscillating hair cells had bandpass response properties (Fig. $4 C$, black) when the small sinusoidal stimulus was delivered around a holding level that generated spontaneous oscillations, and only passive RC responses (Fig. 4C, gray) in response to sinusoidal stimulation around hyperpolarized holding levels that did not generate spontaneous oscillations. Within the oscillating range, shifting the holding current in the depolarizing direction shifted the bandpass envelope to higher frequencies (e.g., from 4 to $30 \mathrm{~Hz}$ in Fig. 4D). In each oscillating hair cell tested, the frequency of highest gain in response to sinusoidal currents matched the frequency of the spontaneous oscillations at the same DC offset. Hair cells classified as nonoscillating (maximum amplitude of spontaneous fluctuations $<7 \mathrm{mV}$ ) showed broader bandpass properties (e.g., Fig. 4 E, black traces) than cells classified as oscillating. Larger depolarizing DC offsets shifted amplification to higher frequencies (Fig. $4 D$ ), up to $\sim 150 \mathrm{~Hz}$ in nonoscillating hair cells and $<100 \mathrm{~Hz}$ for oscillating hair cells (data not shown). 
Frequency-selective amplification (electrical tuning) by hair cells has previously been reported to involve the interaction of $I_{\mathrm{Ca}}$ and $I_{\mathrm{BK}}$ (Crawford and Fettiplace, 1981; Lewis and Hudspeth, 1983; Hudspeth and Lewis, 1988a,b; Fettiplace and Fuchs, 1999). In these cases, frequency selectivity is determined primarily by the amplitude and kinetics of $I_{\mathrm{BK}}$. However another study of isolated frog saccular hair cells (Catacuzzeno et al., 2004) recently reported oscillations that do not involve $I_{\mathrm{BK}}$ or $I_{\mathrm{Ca}}$. To test for the involvement of $I_{\mathrm{BK}}$ we applied the BK-specific blocker, iberiotoxin. Partial block of $I_{\mathrm{BK}}$ via bath application of $100 \mathrm{~nm}$ iberiotoxin (Fig. $4 E$, blue traces) caused larger responses to low-frequency stimuli, and $20 \mathrm{mV}$ oscillations in response to constant holding current, suggesting that $I_{\mathrm{BK}}$ is involved in this cell's responses to sinusoidal and constantcurrent stimuli. The role of membrane currents in shaping the electrical properties of spiking, oscillating, and nonoscillating hair cells in our semi-intact preparation was further investigated in the voltage-clamp experiments described below (Figs. 5-7; supplemental Figs. S2-S4, available at www. jneurosci.org as supplemental material).

\section{Hair cell heterogeneity and the} underlying transmembrane currents Voltage-clamp stimuli were used to assess the amplitudes of depolarizationactivated and hyperpolarization-activated membrane currents present in spiking, oscillating, and nonoscillating hair cells. Spiking cells had smaller outward currents evoked by depolarization (Fig. $5 A$ ) and larger inward currents evoked by hyperpolarization (Fig. $5 B$ ) than nonspiking hair cells. The variability between individual hair cells can be seen in responses to families of voltage-clamp steps, $I-V$ curves, and the corresponding current-clamp traces shown in supplemental Figures S2 and S3 (available at www.jneurosci.org as supplemental material). When the steady-state outward current density for a voltage command $\left(V_{\mathrm{cmd}}\right)$ to $-30 \mathrm{mV}$ was plotted against the steady-state inward current density for $V_{\mathrm{cmd}}=-120 \mathrm{mV}$, the spiking and nonoscillating cells segregated, with oscillators scattered in between (Fig. 5C). The zero-current potentials $\left(V_{\text {rest }}\right)$ ranged from -45 to $-93 \mathrm{mV}$ and were correlated with the steady-state current density in response to hyperpolarization (Fig. 5D). Although they spanned the full range of zero-current potentials and hyperpolarization-activated current densities, on average spiking hair cells had greater hyperpolarization-activated current density $(-73 \pm 11 \mathrm{pA} / \mathrm{pF} ; n=10)$ than nonspiking cells $(-32 \pm 5.8 \mathrm{pA} / \mathrm{pF} ; n=17 ; p=0.0019)$ and more negative zerocurrent potentials $(-74 \pm 3.4 \mathrm{mV})$ than nonspiking cells $(-64 \pm$ $1.9 \mathrm{mV} ; p=0.010)$. Larger steady-state outward current density in response to depolarization $\left(V_{\mathrm{cmd}}=-30 \mathrm{mV}\right)$ was associated with smaller voltage fluctuations (Fig. $5 E$ ) and higher frequencies (Fig. $5 F$ ) in current clamp, although the correlations were weak (see Fig. $5 E, F$ legend).
B

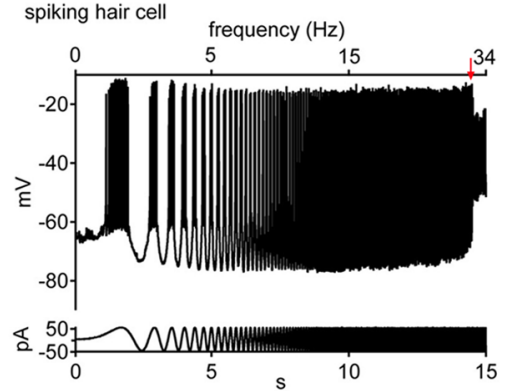

D
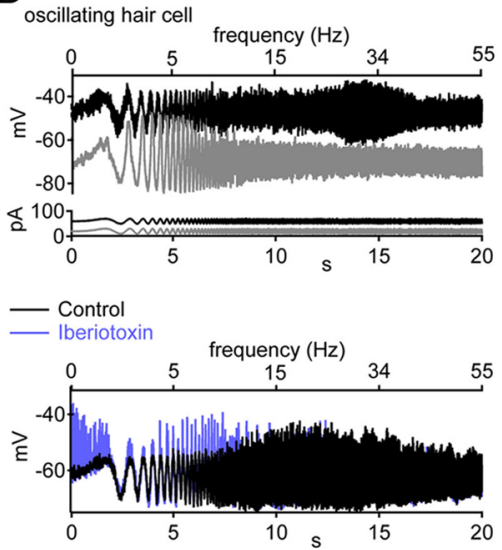

Figure 4. Responses to sinusoidal currents. $A$, Spiking hair cell was held at $I=0$ before application of a $D C+$ sinusoid stimulus $\sim 20$ (red arrow), leaving a smaller oscillatory response to the higher-frequency stimulus. $\boldsymbol{B}$, Another spiking hair cell ceased andpass amplification centered near $20 \mathrm{~Hz}$ in response to stimulation by $80+20 \mathrm{pA}$ (black) but not $40+20 \mathrm{pA}$ (gray). slow appearance of oscillations during the first 2 s after application of the $80 \mathrm{pA}$ offset. $\boldsymbol{D}$, In another oscillating hair cell (perforated , changing the stimulus from $15 \pm 20 \mathrm{pA}$ to $55 \pm 20 \mathrm{pA}$ shifted the envelope of amplification to a higher frequency. $E$, A hair near $20 \mathrm{~Hz}$ (black). Application of $100 \mathrm{~nm}$ iberiotoxin (blue) to block вK $_{\mathrm{BK}}$ caused this cell to generate $20 \mathrm{mV}$ oscillations for DC stimuli, and shifted the center frequency for amplification down by approximately one octave.

Previous studies of dissociated (Hudspeth and Lewis, 1988a,b; Holt and Eatock, 1995; Catacuzzeno et al., 2003a,b, 2004) and nondissociated (Armstrong and Roberts, 1998, 2001) frog saccular hair cells have indicated the importance of six ionic currents for hair cell function. Four are activated by depolarization: $I_{\mathrm{Ca}}$, $I_{\mathrm{KV}}, I_{\mathrm{BK} \text {,steady, }}$ and $I_{\mathrm{BK} \text {,transient }}$. The other two currents are activated by hyperpolarization: $I_{\mathrm{K} 1}$ and mixed potassium/sodium h-current $\left(I_{\mathrm{h}}\right)$. In addition, there have been conflicting reports regarding the presence of an appreciable A-type $\mathrm{K}^{+}$current (Hudspeth and Lewis, 1988a; Holt and Eatock, 1995; Catacuzzeno et al., 2003b) and the small-conductance $\mathrm{Ca}^{2+}$-activated $\mathrm{K}^{+}$(SK) current in frog saccular hair cells (Chabbert, 1997; Armstrong and Roberts, 1998, 2001). If present, the A-current would not be visible in our voltage-clamp recordings due to its voltage-dependent inactivation at the holding potential of $-70 \mathrm{mV}$. The SK current was found in only some cells and was small compared with $I_{\mathrm{BK}}$ or $I_{\mathrm{KV}}$. We therefore focused our analysis on the six aforementioned currents to ask whether any of them could be responsible for the differences between spiking, oscillating, and nonoscillating hair cells.

We separated $I_{\mathrm{Ca}}, I_{\mathrm{BK} \text {,transient }}, I_{\mathrm{BK} \text {,steady }}, I_{\mathrm{KV}}, I_{\mathrm{K} 1}$, and $I_{\mathrm{h}}$ by their known differences in activation kinetics and voltage dependence (Fig. 5G-I) (see Materials and Methods). We did not routinely attempt using channel blockers to characterize ionic currents because there was insufficient time to make the multiple solution 
A means, command to $-30 \mathrm{mV}$

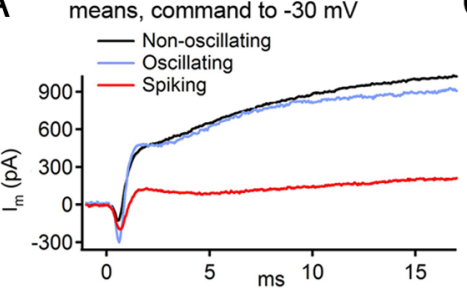

B

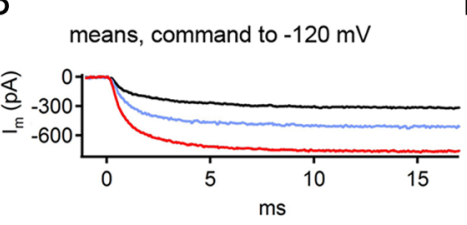

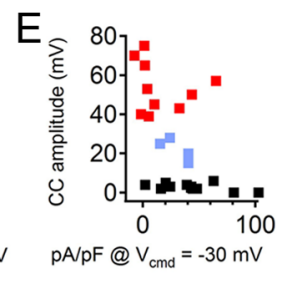

$\mathrm{D}$
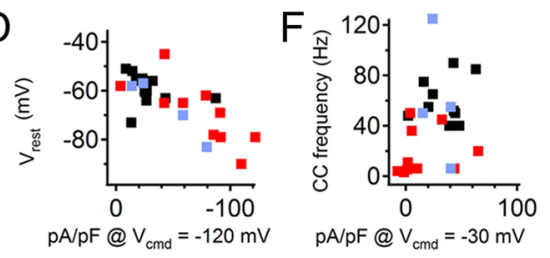

G

G Oscillating Hair Cell: voltage-clamp fits

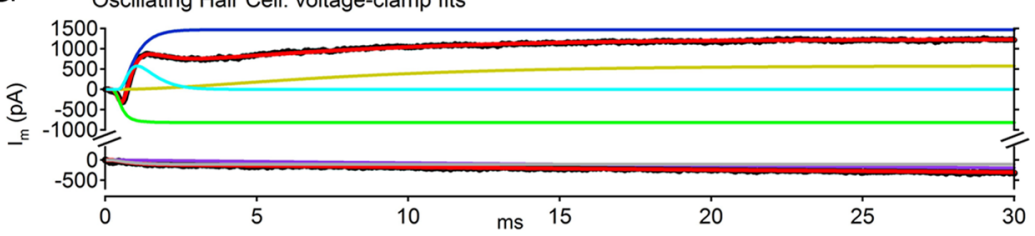

H Spiking Hair Cell: voltage-clamp fits

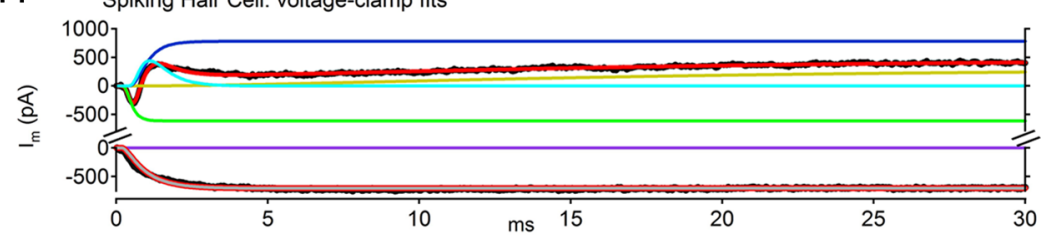

I

fitted current densities (mean \pm s.e.m.) $\quad$ spiking $\square$ oscillating $\square$ non-oscillating

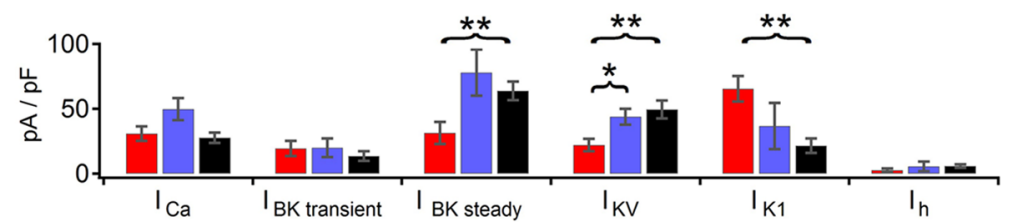

Figure 5. Membrane currents vary between spiking and nonspiking hair cells. $A$, Mean responses to $V_{\text {cmd }}$ steps from -70 to $-30 \mathrm{mV}$ for spiking $(n=10)$, oscillating $(n=4)$ and nonoscillating $(n=13)$ hair cells, leak subtracted (P/10 or P/20) with no series resistance compensation. $\boldsymbol{B}$, Same cells as in $\boldsymbol{A}$ but for $V_{\text {cmd }}$ steps from -70 to $-120 \mathrm{mV}$. C, Scatter plot of steady-state current densities evoked by depolarizing versus hyperpolarizing steps in individual cells. In all but one spiking hair cell, the magnitude of the inward current density at $V_{\mathrm{cmd}}=-120 \mathrm{mV}$ exceeded the outward current density at $V_{\mathrm{cmd}}=-30 \mathrm{mV}$. The opposite was true for nonoscillating hair cells, and oscillating hair cells were intermediate. For $V_{\mathrm{cmd}}=-120 \mathrm{mV}$, there was little overlap in the distributions of current densities between spiking and nonoscillating cells. $\boldsymbol{D}$, Negative correlation between zerocurrent potential $\left(V_{\text {rest }}\right)$ and inward current density at $V_{\text {cmd }}=-120 \mathrm{mV} . \boldsymbol{E}, \boldsymbol{F}$, Amplitude $(\boldsymbol{E})$ and frequency $(\boldsymbol{F})$ of the largest spike, oscillation, or small fluctuation in each cell plotted versus current density at $V_{\mathrm{cmd}}=-30 \mathrm{mV}$. Pearson product-moment correlation coefficients $(r)$ were 0.29 for $\boldsymbol{E}$ and -0.52 for $\boldsymbol{F}$. $\boldsymbol{G}$, Voltage-clamp data (thick black traces, top and bottom) from an oscillating hair cell were well fit (red traces, top and bottom) by the sum of four depolarization-activated currents (top traces: $I_{\text {car }}$ green; $I_{\mathrm{BK}, \text { transient, }}$ light blue; $I_{\mathrm{BK}, \text { steady' }}$ dark blue; $I_{\mathrm{KV}}$, yellow) or two hyperpolarization-activated currents (bottom traces: $I_{\mathrm{K} 1}$, gray; $I_{\mathrm{h}^{\prime}}$ purple). Note the small $I_{\mathrm{h}}$ and $I_{\mathrm{K} 1}$ at $V_{\text {cmd }}=-120 \mathrm{mV}$ in this cell. $\boldsymbol{H}$, same as $\boldsymbol{G}$, for a spiking hair cell that had larger $I_{\mathrm{K} 1}$ and smaller $I_{\mathrm{BK}, \text { steady }}$ and $I_{\mathrm{KV}} \cdot I$, Average fitted current densities (mean $\pm S E M$ ) for spiking, oscillating, and nonoscillating hair cells ${ }^{*} p<0.05$; $\left.{ }^{* *} p<0.01\right)$.

changes needed for a full pharmacological separation of the currents in each cell before the recording degraded in quality. Instead, each hair cell was first characterized in current clamp before we rapidly acquired responses to a family of voltage-clamp steps to assess the ionic currents present. The responses to one depolarizing step $\left(V_{\mathrm{cmd}}=-30 \mathrm{mV}\right)$ and one hyperpolarizing step $\left(V_{\mathrm{cmd}}=-120 \mathrm{mV}\right.$ ) were sufficient to separate the six currents. The separation of ionic conductances was based on published models of ion channel kinetics in frog saccular hair cells, except for BK channel inactivation, which required modification of the published model to obtain good fits to our data (see Mate- rials and Methods). The fitting procedure always converged to the same set of parameter values regardless of the seed values, indicating that the solution was well constrained. Nevertheless, we regard the fitted values as approximate.

Examples of the fits are shown for an oscillating hair cell (Fig. 5G) and a spiking hair cell (Fig. 5H). Separation of the depolarization-activated currents relied on the fact that for $V_{\mathrm{cmd}}=-30 \mathrm{mV}, I_{\mathrm{Ca}}$ activated very rapidly $\left(\tau_{\mathrm{Ca}}=110 \mu \mathrm{s}\right)$ compared with $I_{\mathrm{KV}}$ and $I_{\mathrm{BK}}$ (Armstrong and Roberts, 1998). $I_{\mathrm{BK}}$ requires $\mathrm{Ca}^{2+}$ influx provided by $I_{\mathrm{Ca}}$, ensuring a brief delay before $I_{\mathrm{BK}}$ activation produced a net outward current, which occurred by $t=2 \mathrm{~ms}$ following a step to $-30 \mathrm{mV}$. In most hair cells $I_{\mathrm{BK}}$ partially inactivated, resulting in transient and steady components. $I_{\mathrm{KV}}$ was the slowest outward current to activate $\left(\tau_{\mathrm{KV}}>5 \mathrm{~ms}\right)$. An important check of the validity of the fitting procedure was that the mean $I_{\mathrm{Ca}}(407 \pm 41 \mathrm{pA}$; mean $\pm \mathrm{SEM}$, $n=26$ ) was similar to the value measured by pharmacological isolation in previous studies using the same semi-intact preparation [Armstrong and Roberts (1998): $363 \pm 46 \mathrm{pA}, n=10$; Rutherford and Roberts (2006): $335 \pm 15 \mathrm{pA}, n=95] . I_{\mathrm{K} 1}$ and $I_{\mathrm{h}}$ were easily separated at $V_{\mathrm{cmd}}=$ $-120 \mathrm{mV}$ because of their thousandfold difference in activation time constants (1 $\mathrm{ms}$ vs $1000 \mathrm{~ms}$ ). Most of the hair cells in our sample expressed all six of the currents, but in different amounts.

The main difference in the currents activated by depolarization was that spiking hair cells had smaller net outward current than nonspiking hair cells (Fig. $5 A$ ) because they had only about half as much $I_{\mathrm{BK} \text {,steady }}$ and $I_{\mathrm{KV}}$ (Fig. $5 I$ ). There were no significant differences in $I_{\mathrm{Ca}}$ or $I_{\mathrm{BK} \text {,transient }}$ (Fig. 5I). Spiking hair cells had lower $I_{\mathrm{KV}}$ current density $(21.9 \pm 4.9 \mathrm{pA} / \mathrm{pF} ; n=$ 10) than oscillating hair cells $(43.9 \pm 5.9$ $\mathrm{pA} / \mathrm{pF} ; n=4 ; p=0.023$ ) or nonoscillating hair cells $(49.5 \pm 6.8 \mathrm{pA} / \mathrm{pF} ; n=12 ; p=$ $0.003)$, and lower $I_{\mathrm{BK} \text {,steady }}$ current density $(31.4 \pm 8.5 \mathrm{pA} / \mathrm{pF} ; n=10)$ than nonoscillating hair cells $(63.9 \pm 7.1 \mathrm{pA} / \mathrm{pF} ; n=12$; $p=0.008)$ or all nonspiking hair cells $(67.4 \pm 6.8 ; n=16 ; p=0.003)$. In addition to being smaller, $I_{\mathrm{KV}}$ activated more slowly in spiking hair cells $\left(\tau_{\mathrm{KV}}=13.6 \pm 2.0 \mathrm{~ms}\right.$, $n=9$, one cell excluded because $I_{\mathrm{KV}}$ was too small to measure $\left.\tau_{\mathrm{KV}}\right)$ than in nonspiking cells $\left(\tau_{\mathrm{KV}}=6.1 \pm 0.3, n=16 ; p=\right.$ $0.004)$.

Although $I_{\mathrm{BK} \text {,transient }}$ current densities did not differ significantly by cell type (Fig. $5 I$ ), $I_{\mathrm{BK} \text {,transient }}$ was most prominent in spiking hair cells because they typically had smaller steady-state outward currents (Fig. 5A). In some spiking hair cells, inactivation of $I_{\mathrm{BK} \text {,transient }}$ resulted in a net inward current $5 \mathrm{~ms}$ after a step to $-40 \mathrm{mV}$ (red traces in the left panels of Fig. $6 \mathrm{~A}$ and supple- 
A
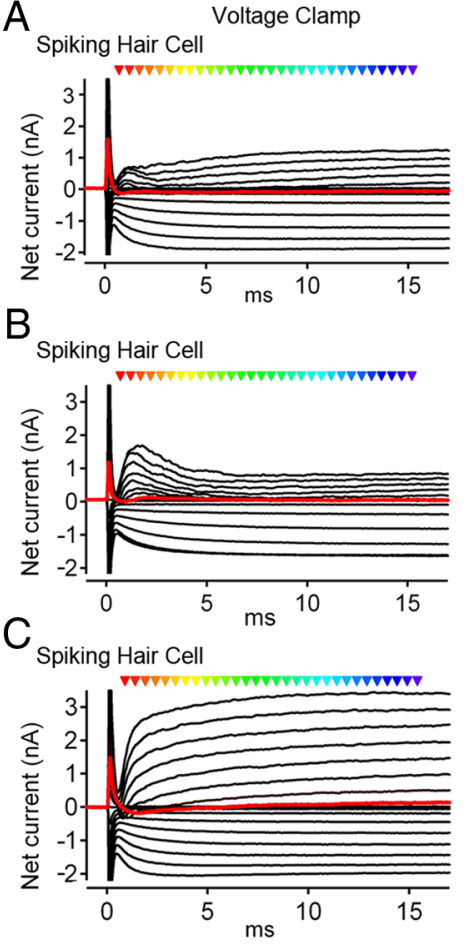

I-V
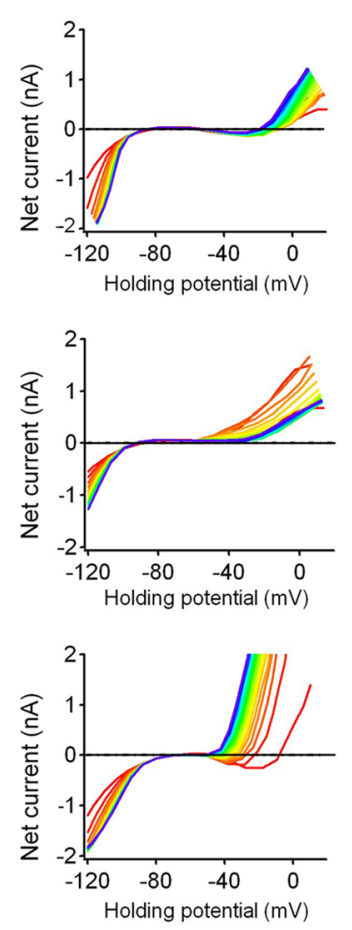
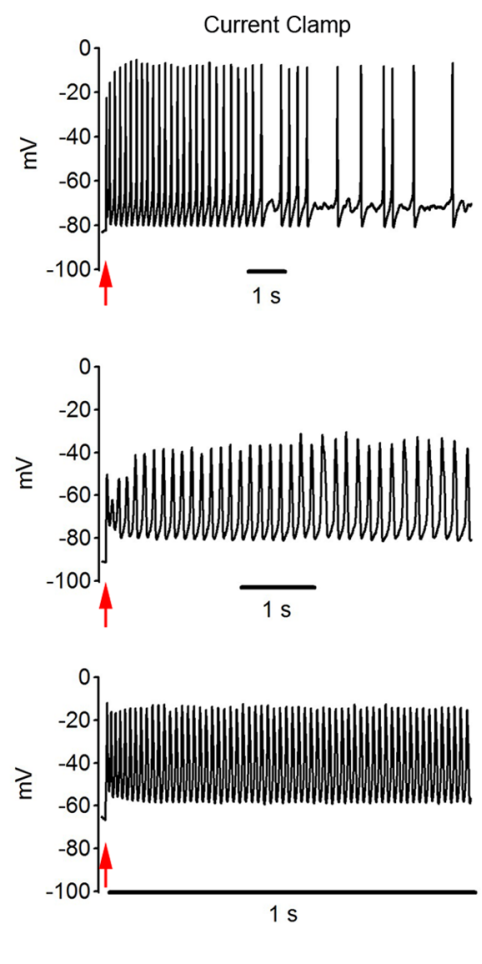

Figure 6. Variability within the class of spiking hair cells. $A-C$, Voltage clamp (left), current-voltage relationships (middle), and current clamp samples from three different spiking hair cells. Voltage-clamp records are individual traces of net current without $\mathrm{RC}$ compensation or leak subtraction. From the holding potential of $-70 \mathrm{mV}, 50 \mathrm{~ms}$ steps were delivered in $10 \mathrm{mV}$ increments in the range of -150 to $+30 \mathrm{mV}$. Some traces were removed for clarity. Red traces are for $V_{\text {cmd }}=-40 \mathrm{mV}$. After the capacitive transient crossed zero current (at $\sim 0.4 \mathrm{~ms}$ ), the trace was divided into $0.5 \mathrm{~ms}$ windows (rainbow colored markers) for calculating the current-voltage relationships, which were corrected for series resistance errors based on the net current in each time window. Note the different $x$-axis scales for the current-clamp data. The red arrows denote the onset of a current step of $+50 \mathrm{pA}$ in $\boldsymbol{A}$ and $+100 \mathrm{pA}$ in $\boldsymbol{B}$ and $\boldsymbol{C}$. $\boldsymbol{A}$, In current clamp, a "phasic" (completely adapting) hair cell fired a train of large amplitude spikes at step onset and then stopped. In the current-voltage plot, note the small but persistent net inward current for potentials between -45 and $-15 \mathrm{mV}$. B, Repetitively firing hair cell at low frequency. C, Repetitively firing hair cell at higher frequency (perforated-patch recording).

mental Figs. S2 A, S3A, available at www.jneurosci.org as supplemental material). In nonspiking hair cells, $I_{\mathrm{BK}, \text { transient }}$ was a smaller fraction of the total outward current (Fig. $5 A, G, I$; supplemental Figs. S2 $B, C, \mathrm{~S} 3 B-D$, available at www.jneurosci.org as supplemental material), and its inactivation did not result in net inward current.

$I_{\mathrm{K} 1}$ was the predominant hyperpolarization-activated current in all three groups, and significantly larger in spiking hair cells (69.8 \pm $10.6 \mathrm{pA} / \mathrm{pF} ; n=10)$ than in nonoscillating hair cells $(22.7 \pm 6.2$ $\mathrm{pA} / \mathrm{pF} ; n=12 ; p=0.001)$ or all nonspiking hair cells $(26.5 \pm 6.4$ $\mathrm{pA} / \mathrm{pF} ; n=16 ; p=0.003)$. We found no significant differences in $I_{\mathrm{h}}$ across groups. Thus the predominant determinant of the relationship between hyperpolarization-activated current density (in picoamperes per picofarad at $V_{\mathrm{cmd}}=-120 \mathrm{mV}$ ) and zerocurrent potential $\left(V_{\text {rest }}\right)$ in Figure $5 D$ appears to be $I_{\mathrm{K} 1}$; hair cells with greater $I_{\mathrm{K} 1}$ current density have a more negative resting potential and tend to be spiking hair cells.

\section{Heterogeneity among spiking hair cells}

Variability within the spiking phenotype was assessed by comparing voltage- and current-clamp data between cells (Fig. 6). Cells with similar currents evoked by hyperpolarization $\left(I_{\mathrm{K} 1}\right.$ and $\left.I_{\mathrm{h}}\right)$ had different depolarization-activated currents and different spike patterns. The cell with the smallest fast outward current $\left(I_{\mathrm{BK}}\right)$ (Fig. 6A, left, center) had the largest spike $(75 \mathrm{mV})$ (Fig. 6A, right) and a low spike frequency (note the different timescales for current clamp in Fig. 6, right). The cell with the largest fast and steady outward currents $\left(I_{\mathrm{BK}}+I_{\mathrm{KV}}\right)$ (Fig. $6 C$, left) had the smallest spike $(39 \mathrm{mV})$ (Fig. $6 C$, right) and the highest repetitive firing frequency $(67 \mathrm{~Hz}$ in response to $+100 \mathrm{pA})$. As expected, the fast, large, and sustained outward current was associated with fast repolarization in current clamp, generating small spikes with a short duration required for a high firing rate (Fig. $6 C$, right). Also note the presence of unusually large initial net inward current apparent in the rainbow $I-V$ plot (Fig. $6 C$, middle), to support rapid spike depolarization. The hair cell with the smallest steady outward current $\left(I_{\mathrm{BK} \text {,steady }}+I_{\mathrm{KV}}\right)$ (Fig. $6 B$ ) had slow postspike repolarization, broad spikes, and a low firing rate $(6 \mathrm{~Hz}$ in response to $+40 \mathrm{pA}$ ).

Spikes are generated by $\mathrm{Ca}^{2+}$ influx through L-type channels and suppressed in hair cells that have large $I_{\mathrm{BK}}$

To test for the involvement of $I_{\mathrm{Ca}}$ and $I_{\mathrm{BK}}$ in hair cell spikes, we recorded voltage-clamp and current-clamp data in normal extracellular saline, then added the BK-specific blocker iberiotoxin (100 nM) to the extracellular solution to reduce the amplitude of $I_{\mathrm{BK}}$, or nifedipine $(50 \mu \mathrm{M})$ to reduce calcium influx through L-type channels. Because $I_{\mathrm{Ca}}$ tends to run down over several minutes in the ruptured-patch configuration, perforated patch was used in these experiments.

The current blocked by $100 \mathrm{~nm}$ iberiotoxin (e.g., Fig. 7A, red trace) had a transient component (peak amplitude $=413 \pm 138$ $\mathrm{pA}$ for voltage commands to $-30 \mathrm{mV}, n=8$ ) and a smaller sustained component. Some of these cells did not fire spikes in normal extracellular saline, but did after addition of iberiotoxin (see supplemental Fig. S4, available at www.jneurosci.org as supplemental material). The cell shown in Figure $7 B$ fired spikes only sporadically under control conditions (current clamp, black 

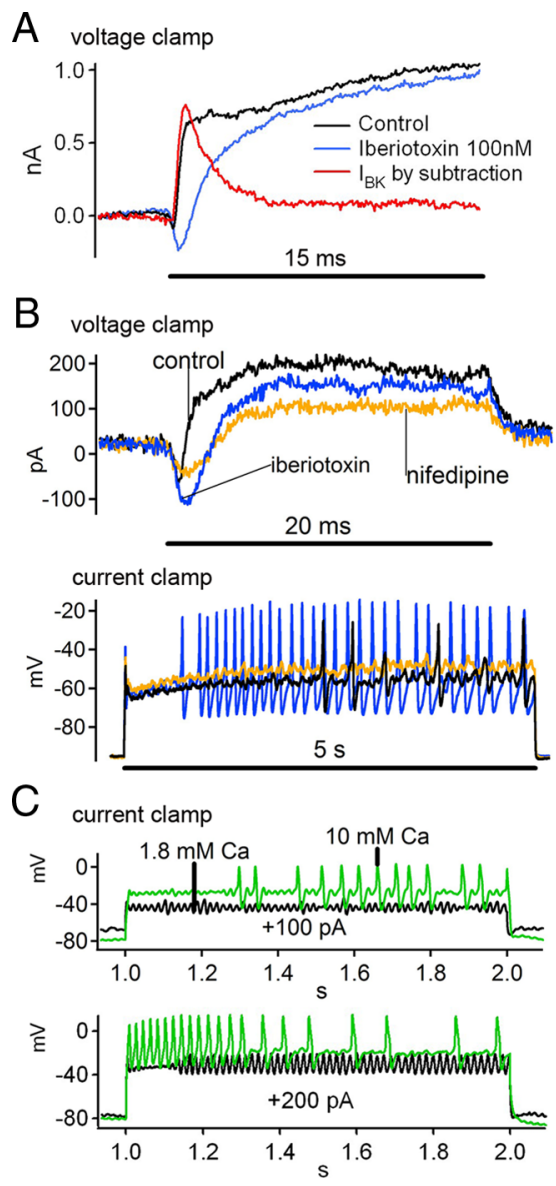

Figure 7. Influence of $I_{\mathrm{Ca}}$ and $I_{\mathrm{BK}}$ on hair cell spikes in the frog sacculus. $\boldsymbol{A}$, Leak-subtracted $(\mathrm{P} / 10)$ voltage-clamp traces in response to depolarizing commands from -70 to $-30 \mathrm{mV}$ before (black) and after (blue) adding $100 \mathrm{~nm}$ iberiotoxin to the bath to partially block $\mathrm{BK}_{\mathrm{BK}}$. The blocked current was calculated by subtraction (red). Note the more obvious inward $\mathrm{Ca}^{2+}$ current after removing $I_{\mathrm{BK}}$ by treatment with iberiotoxin. $\boldsymbol{B}$, Top, Leak-subtracted $(\mathrm{P} / 10)$ voltageclamp traces for $20 \mathrm{~ms}$ steps to $-30 \mathrm{mV}$ for control (black), $100 \mathrm{~nm}$ iberiotoxin (blue), and 100 $\mathrm{nm}$ iberiotoxin $+50 \mu \mathrm{m}$ nifedipine (yellow). Bottom, Current-clamp records for $5 \mathrm{~s}$ steps from 0 to $+100 \mathrm{pA}$ delivered to the cell in $\boldsymbol{B}$ under each pharmacological condition. Spikes were promoted by iberiotoxin, and then abolished by nifedipine. $\boldsymbol{C}$, An oscillating hair cell in response to 1 s current clamp stimuli to $+100 \mathrm{pA}$ (top) and $+200 \mathrm{pA}$ (bottom) in normal ( $1.8 \mathrm{~mm}$, black) or high (10 mm, green) extracellular $\mathrm{Ca}^{2+}$.

trace). After addition of iberiotoxin (blue trace) the spikes became larger and much more frequent. On average, the maximum oscillation or spike amplitude in current clamp was increased significantly upon bath application of $100 \mathrm{~nm}$ iberiotoxin (22.2 \pm 11.5 vs $25.7 \pm 12.3 \mathrm{mV}, n=8, p=0.034$, one-tailed paired $t$ test). The effect of iberiotoxin on frequency was more complex. Spiking hair cells tended to increase their firing rate, while oscillating cells began spiking at a lower frequency. On average, the frequency that corresponded to the maximum amplitude decreased with application of iberiotoxin $(55.4 \pm 14.9$ vs $51.7 \pm 19.7 \mathrm{~Hz}$, $n=8, p=0.43$ ), but the difference was not significant. The effects of iberiotoxin on amplitude and frequency in current clamp experiments were in agreement with the general trends across all cells: as the outward current density at $-30 \mathrm{mV}$ decreased, the amplitude increased and the frequency decreased (Fig. $5 E, F$ ).

Bath application of $50 \mu \mathrm{M}$ nifedipine reduced but did not completely block the initial inward current evoked by depolarization (Fig. $7 B$, yellow voltage-clamp trace), and abolished spiking in 3 out of 3 hair cells that fired spikes in normal extracellular saline. Nifedipine also blocked spikes induced by iberiotoxin
(Fig. 7B, yellow current-clamp trace). These observations demonstrate that spikes in frog saccular hair cells require $I_{\mathrm{Ca}}$ through L-type channels. Conversely, augmenting the calcium current with high extracellular calcium promoted spikes. The cell shown in Figure $7 C$ was converted from oscillating in normal $(1.8 \mathrm{~mm}$ $\mathrm{Ca}^{2+}$ ) extracellular saline (black traces) to spiking in $10 \mathrm{mM} \mathrm{Ca}^{2+}$ (green traces).

\section{Afferent neuronal innervation and postsynaptic sodium channel labeling in the saccular macula}

Hair cells in the frog sacculus make synaptic connections onto postsynaptic boutons of afferent VIIIth nerve fibers, as shown in Figure 8. We reasoned that if ongoing spikes or large oscillations triggered neurotransmitter release from hair cells, the pattern of presynaptic voltage fluctuations should be reflected in recordings of EPSPs and perhaps action potentials from the afferent neurites in the semi-intact preparation. From the cell body (Fig. $8 \mathrm{~A}$, bottom right), each afferent neuron sends one myelinated axon centrally to the brainstem (data not shown) and another peripherally to the sensory epithelium (saccular macula) (Fig. 8 A, top). Afferent axons shed their myelin as they cross the basement membrane a few $\mu \mathrm{m}$ below the synaptic layer and immediately branch into two or more nonmyelinated neurites, sometimes from a varicosity that could be seen in the furrowed living epithelium (Fig. 8D) and in fixed tissue that had not been furrowed (Fig. $8 \mathrm{~A}$, top inset). Nonmyelinated neurites make postsynaptic contacts with multiple hair cells (schematized in Fig. 8 B). A monoclonal panvoltage-gated sodium channel $\left(\mathrm{Na}_{\mathrm{V}}\right)$ antibody strongly labeled the first branch point (forked structures in Fig. $8 E$ ). We did not observe the diffuse $\mathrm{Na}_{\mathrm{V}}$ labeling on distal afferent neurites or at postsynaptic terminals that was seen in the mammalian cochlea using the same antibody (Hossain et al., 2005). A monoclonal neurofilament antibody (3A10) strongly labeled nonmyelinated neurites throughout the sensory epithelium (Fig. $8 F$ ), similar to the amphibian papilla of the frog (Keen and Hudspeth, 2006).

To determine whether spontaneous activity in hair cells could cause transmitter release, we made whole-cell recordings from postsynaptic afferent neurites, exercising care to preserve the delicate synapses in the semi-intact preparation. The recordings sites were located between postsynaptic boutons and the branch points containing the $\mathrm{Na}_{\mathrm{V}}$ labeling. One or more hair cellafferent contact sites were often visible within $20 \mu \mathrm{m}$ of the recording site (Fig. $8 B, C$ ) and additional unseen synaptic contacts may have been present. Furrowing the epithelium severed some neurite branches and disrupted some synapses. Some neurites had resting potentials near $-70 \mathrm{mV}$, but many were more depolarized, possibly due to damage at the recording site, at the cut end of the myelinated axon, or in other branches of the neurite. We therefore applied a holding potential in voltage clamp, or holding current in current clamp, to bring the baseline membrane potential to near $-80 \mathrm{mV}$. Amiloride $(100 \mu \mathrm{M})$ was present in the bathing medium to block MET.

Intracellular recordings from postsynaptic afferent neurons Approximately half (10/22) of the successful intracellular recordings (see Materials and Methods) showed vigorous synaptic activity. The remainder (12/22) had only irregular low-frequency synaptic events or no evidence of synaptic activity. Of the 10 recordings with vigorous synaptic activity, two had continuous highly periodic $(\sim 5 \mathrm{~Hz})$ bursts of EPSP events for the duration of the recording $(60-300 \mathrm{~s})$, four had intermittent bouts of periodic synaptic events at $25-70 \mathrm{~Hz}$ separated by longer silent periods, and four had complex patterns that in some cases appeared to 
consist of several uncoupled rhythms. This spontaneous periodic excitation in afferent neurites suggests that frog saccular hair cells are capable of periodic transmitter release in the same frequency range as their spontaneous spikes and oscillations.

Figure $9 A$ presents voltage-clamp data from an afferent fiber with intermittent periodic synaptic activity. EPSC activity first appeared as unitary events (Fig. 9A, top trace) that then began to superimpose into small bursts. Subsequent EPSC bursts became larger and more periodic (Fig. 9A, bottom trace), sometimes eliciting action potentials, evident as action currents. The periodicity of this afferent activity over many cycles is demonstrated in supplemental Figure S1 (available at www. jneurosci.org as supplemental material).

In other afferent fibers as well, bursts of EPSPs in current clamp (Fig. 9B1) and EPSCs in voltage clamp (Fig. 9B2,C) were usually composed of many superimposed events (Fig. 9B1,B2, bottom traces), but occasionally contained only a few widely spaced events (top traces). Individual events typically had submillisecond rise times, durations of $\sim 5 \mathrm{~ms}$, and could vary tenfold in amplitude within a single burst (compare the largest and smallest of the five events in the top trace of Fig. 9B1). Bursts were separated by periods of inactivity that lasted for tens to hundreds of milliseconds. Figure 9C1 shows EPSCs from another cell, in which bath application of CNQX $(10 \mu \mathrm{M})$ reduced the EPSC amplitude by $>75 \%$ (Fig. 9C2), confirming their identity as glutamatergic EPSCs through AMPA-type receptors (Glowatzki and Fuchs, 2002; Holt et al., 2006; Keen and Hudspeth, 2006).

To look for the effects of hair cell $\mathrm{K}^{+}$ currents on EPSC properties, we replaced the normal artificial perilymph $(2 \mathrm{~mm}$ $\mathrm{K}^{+}$) with high- $\mathrm{K}^{+}$artificial perilymph $\left(40 \mathrm{mM} \mathrm{K}^{+}\right)$, which depolarizes hair cells by $\sim 30 \mathrm{mV}$ (data not shown). TTX was present in the bath to block spikes in the afferent axon throughout this experiment. Before application of high $\mathrm{K}^{+}$(Fig. $10 \mathrm{~A}$ ), EPSCs occurred in bursts that repeated at intervals of $\sim 150 \mathrm{~ms}$, or integer multiples thereof. The periodicity of EPSC bursts despite frequent skipped fundamental intervals [Fig. 10A1 (bottom trace), A2] demonstrates that failures of synaptic vesicle exocytosis can occur while the periodicity of subsequent synaptic activity is preserved. Upon addition of high $\mathrm{K}^{+}$, periodic EPSC bursts disappeared and were replaced by a high-frequency barrage of irregularly timed EPSCs (Fig. $10 \mathrm{~B}, \mathrm{C}$ ). This increase in EPSC rate $\left(14 s^{-1}\right.$ to $52 s^{-1}$, mean over $\left.30 s\right)$ was accompanied by
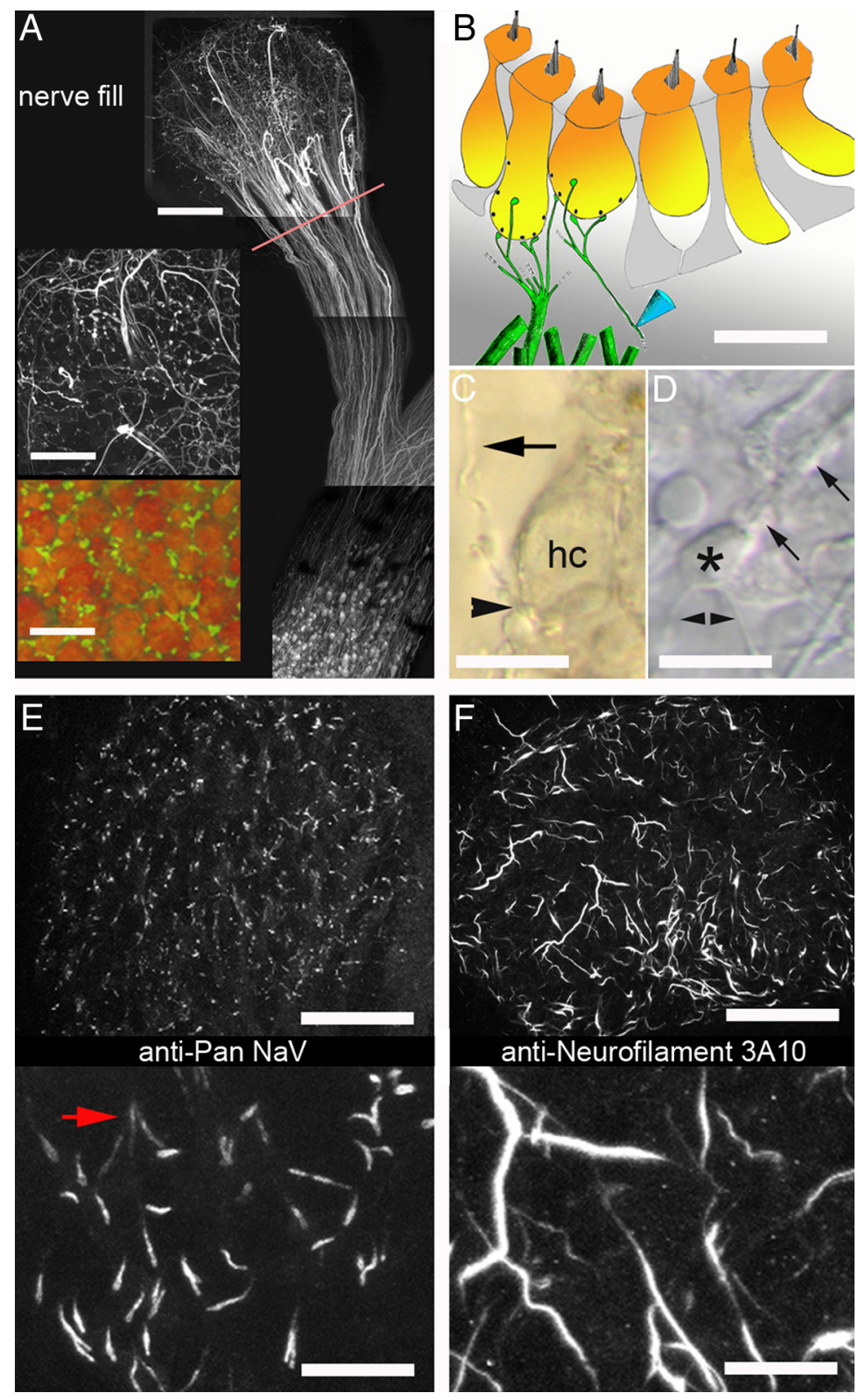

Figure 8. Innervation of the frog sacculus. A, Axons visualized by confocal microscopy after backfilling the anterior branch of the VIIIth cranial nerve with fluorescein-dextran. Afferent neuron somata (bottom right) that innervate the sacculus, utriculus, and the anterior and lateral semicircular canals can be seen proximal to the divergence of the saccular branch. The saccular macula (top center) glows with the diffuse fluorescence of many small axons. Most of the brightly stained (large-diameter) axons shed their myelin near the proximal margin of the macula, a few at the lateral and distal margins. Top inset, Small-diameter neurites make multiple synaptic contacts (bright spots) as they weave between hair cells (dark circles). Bottom inset, Numerous terminal and en passant boutons (green; fluorescein- dextran) contact each hair cell (red; FM1-43 stain). For electrical recordings from the semiintact epithelium, the nerve was cut short (red line). $\boldsymbol{B}$, Schematic shows placement of the recording electrode (blue) on a fine neuritic branch. C, DIC image of a furrowed epithelium shows a neurite (arrow) making a bouton contact (arrowhead) onto a hair cell (hc). $\boldsymbol{D}$, At the level of the basement membrane, a myelinated axon (arrows) expands into an nonmyelinated varicosity $\left({ }^{*}\right)$. It then branches into slender nonmyelinated neurites (arrowheads) that extend into the synaptic layer above the basement membrane, becoming accessible to recording electrodes. To the top left is a damaged axon in which the varicosity has been disconnected from the myelinated segment. $\boldsymbol{E}$, A monoclonal pan- $\mathrm{Na}_{\mathrm{V}}$ channel antibody (Rasband et al., 1999) labeled neurites near the basement membrane, often at the first branch point (entire macula shown above, enlargement below). Na channel clusters extended 2-5 $\mu \mathrm{m}$ into each branch (forked structures in bottom; red arrow points to a trifurcation). $\boldsymbol{F}$, Neurofilament antibody (3A10) strongly labeled nonmyelinated neurites (entire macula shown above, enlargement below). Scale bars (in $\mu \mathrm{m}$ ): $\boldsymbol{A}, 50$ (right), 20 (top inset), 15 (bottom inset); $\boldsymbol{B}, 10 ; \boldsymbol{C}, \boldsymbol{D}, 5 ; \boldsymbol{E}, \boldsymbol{F}, 50$ (top), 10 (bottom). an increase in the size of EPSC events (Fig. 10D). A similar result was reported in the frog's amphibian papilla when hair cells were depolarized using a whole-cell pipette (Keen and Hudspeth, 2006). In contrast, depolarizing mouse cochlear inner hair cells 
A afferent fiber synaptic activity and action currents $V_{\text {hold }}=-80 \mathrm{mV}$, no stimulus applied

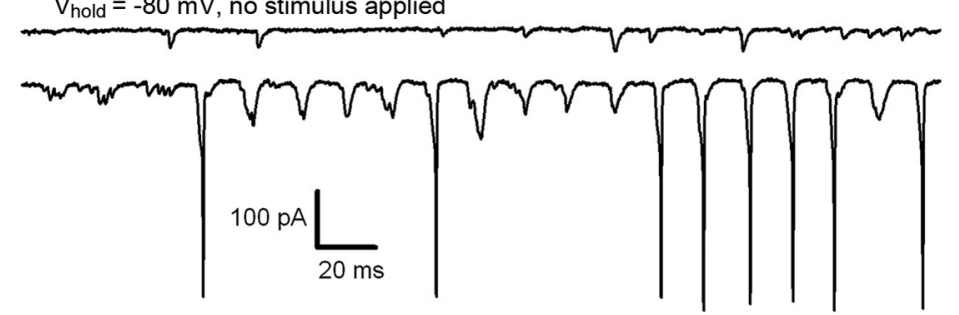

B1 current clamp

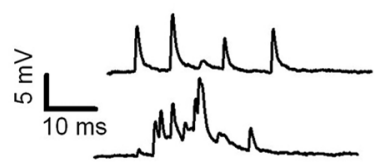

C1 voltage clamp

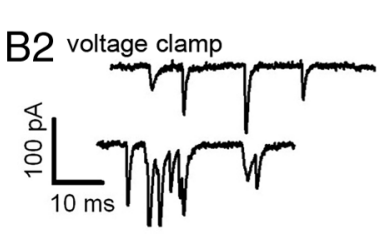

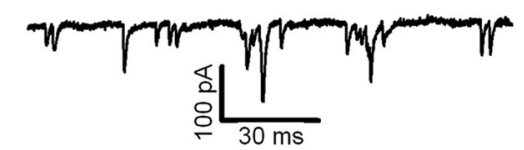

$\mathrm{C} 2$
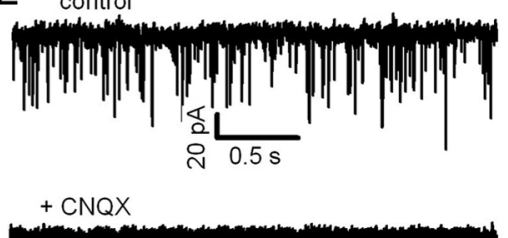

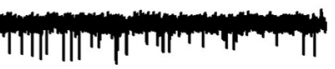

Figure 9. Bursts of background synaptic activity in postsynaptic fibers are composed of brief individual events sensitive to CNQX. $A$, Two lines of continuous data acquired at the onset of periodic synaptic activity show discrete EPSC-events that superimpose into bursts. Large bursts triggered all-or-none action potentials (evident as action currents) in afferent neurites that escaped voltage clamp $\left(V_{\text {cmd }}=-80 \mathrm{mV}\right)$. B, Examples of subthreshold activity in current clamp (B1) and voltage clamp (B2). Each of the four traces shows one burst. C, EPSC bursts (C1) from a different cell were 75\% blocked by adding $10 \mu \mathrm{m}$ CNQX to the bath (C2). No action potentials occurred in $\boldsymbol{B}$ and $\boldsymbol{C}$.

with high $\mathrm{K}^{+}$or current injection increased the rate but not the size of EPSCs (Glowatzki and Fuchs, 2002; Goutman and Glowatzki, 2007).

\section{Discussion}

Frog saccular hair cells expressed a diverse range of spontaneous electrical activity. Half had small $(<7 \mathrm{mV})$ steady-state membrane potential fluctuations, while the others produced all-ornone spikes or variable-amplitude sustained oscillations. Spikes and oscillations sometimes occurred without any applied current (Fig. 1), while other cells required small (25-100 pA) steady depolarizing current (Figs. 2, 3). In vivo, a depolarizing current of this magnitude $(50-100 \mathrm{pA})$ is generated by the $15-20 \%$ activation of MET with the hair bundle in the resting position (Corey and Hudspeth, 1983; Shepherd and Corey, 1994). Thus, it is possible the oscillations and spikes we observed in response to small depolarizing holding currents represent resting behaviors of some frog saccular hair cells in vivo.

Spikes and oscillations occurred in a voltage range that evokes calcium-dependent exocytosis of neurotransmitter (Rutherford and Roberts, 2006), and thus could establish the background spike pattern in afferent neurons. To test this possibility, we recorded from neurites close to postsynaptic sites, and found periodic EPSCs that were sensitive to CNQX (Figs. 9, 10), indicating glutamatergic transmission involving AMPA receptors. Hair cells provide the only known source of glutamatergic input to afferent neurites. In some postsynaptic recordings EPSC bursts occurred with remarkable long-term periodicity that was not interrupted by missed cycles (Fig. 10 A), suggesting that a presynaptic hair cell was generating a spontaneous periodic oscillation or repetitive spike train that evoked periodic transmitter release, with failures on some cycles. Transmission may be further enhanced at some frequencies by intrinsic frequency selectivity of synaptic exocytosis (Rutherford and Roberts, 2006). As expected for a voltage-dependent presynaptic mechanism, depolarization by high $\mathrm{K}^{+}$increased the EPSC frequency and disrupted the timing (Fig. $10 B, C$ ). A tight association of afferent action potentials with bursts of excitatory synaptic input was seen in current-clamp recordings and under voltage clamp in cases where the spike generator escaped voltage control (Fig. $9 A$ ), indicating that neural spikes were triggered periodically in response to cycles of presynaptic depolarization. In vivo, some frog saccular afferent axons have a periodic spike pattern in the absence of a stimulus, and respond to weak vibratory stimuli by phase locking to the stimulus without an increase in spike rate (Koyama et al., 1982; Christensen-Dalsgaard and Narins, 1993). This can be explained by entrainment of spontaneous hair cell spikes or oscillations (Fig. 4).

The properties of nonspiking hair cells were consistent with their involvement in electrical tuning. We classified nonspiking hair cells as oscillating or nonoscillating depending on whether or not they generated large oscillations during steady holding currents, but both types showed frequency selectivity when a sinusoidal stimulus was applied (Fig. 4C-E). In oscillating hair cells, the peak sensitivity to sinusoidal current coincided with the oscillation frequency evoked by the holding current alone. If spontaneous oscillations occur in vivo, the faintest sounds would be encoded by modulation of the ongoing pattern rather than by the appearance of a signal upon an otherwise stable resting potential.

Oscillation frequencies were within the range of best frequencies for saccular afferents in this species $(20-70 \mathrm{~Hz})$ (Christensen-Dalsgaard and Narins, 1993), which coincides with the power spectrum of seismic waves in response to impulsive stimuli such as footsteps (Lewis and Narins, 1985; Lewis et al., 2001). In most oscillating hair cells, frequency increased with holding current up to a plateau at $40-70 \mathrm{~Hz}$ (Fig. $5 F$ ). The peakpower frequency of nonoscillating hair cells also increased with holding current, and extended to somewhat higher frequencies (Fig. $5 F$ ). In vivo, frequency selectivity in these nonspiking hair cells is therefore expected to vary with steady-state activation of MET channels and other factors, such as efferent inhibition.

Spiking hair cells fired at up to $66 \mathrm{~Hz}$ in response to sustained holding currents (Figs. 3B, 6C), and responded to sinusoidal inputs in the low-frequency range of saccular sensitivity (Fig. $4 A, B)$. They were found throughout the macula but were concentrated in the outer 3 hair cell rows, where cells are predominantly tall and thin (Chabbert, 1997), express both calretinin (Edmonds et al., 2000) (supplemental Fig. S5A, available at www. jneurosci.org as supplemental material) and parvalbumin 3 (Heller et al., 2002), and have long kinocilia (Díaz et al., 1995). Most spiking cells in the outer three rows sustained repetitive firing at a rate that varied with the holding current (Figs. $2 A, B, 3 B$ ), suggesting that they respond to very-low-frequency stimuli, possibly 


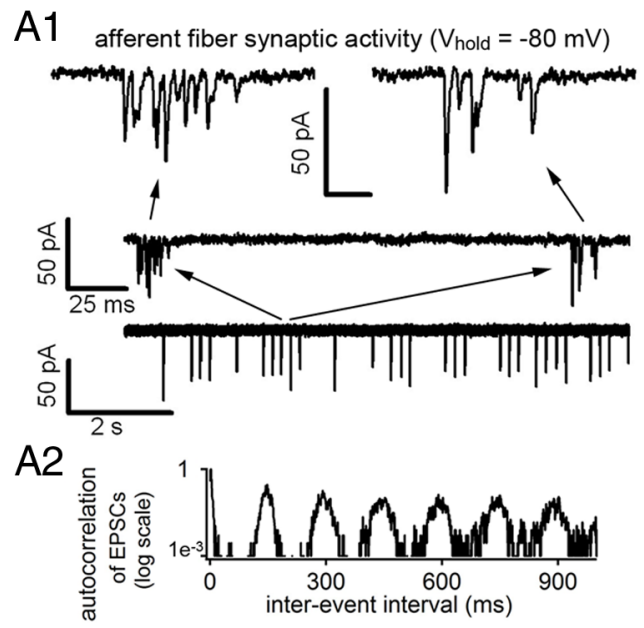

B

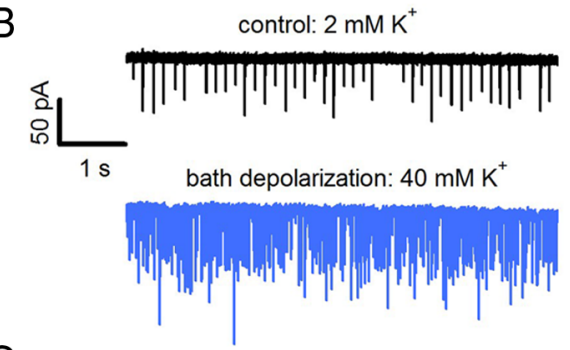

C

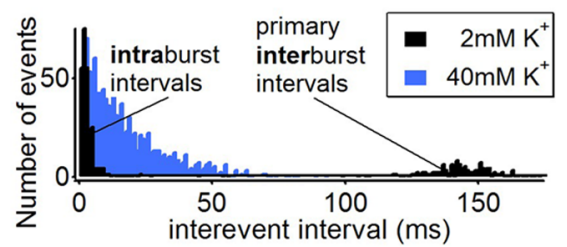

D

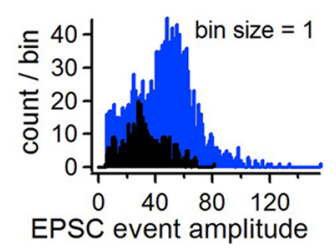

$E$

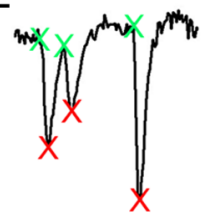

Figure 10. Periodic EPSC burst activity at rest is abolished in high $\mathrm{K}^{+}$. A1, EPSP bursts displayed on three different timescales, with $1 \mu \mathrm{M}$ TTX in the bath to prevent spiking. Bursts were $10-35 \mathrm{~ms}$ in duration and contained a variable number of EPSC-events of variable amplitude (top trace). EPSCs were absent between bursts (middle trace). The intervals between bursts (bottom trace) were approximately integer multiples of $150 \mathrm{~ms}$. A2, Autocorrelation (normalized log scale, $y$-axis) of EPSC-event times for the same cell showed preferred EPSCevent intervals (in milliseconds, $x$-axis). The large peak near 0 ms represents the short intervals within a burst. The broad peaks centered near $150 \mathrm{~ms}$ and multiples thereof represent the periodicity of successive bursts, despite skipped fundamental intervals. $\boldsymbol{B}$, Data obtained later in the same recording, immediately before (black) and after (blue) a change of the extracellular medium from 2 to $40 \mathrm{~mm} \mathrm{~K}^{+}$. C, Histogram of intervals between EPSC-events before solution exchange (black) shows short intervals that correspond to closely spaced EPSC-events within each burst, and long intervals that correspond to the time between the last event in one burst and the first event in the next. After solution exchange (blue), the interval histogram showed an exponential distribution characteristic of a Poisson process. $\boldsymbol{D}$, Bath depolarization with high $\mathrm{K}^{+}$resulted in larger EPSC events compared with control. Data from $30 \mathrm{~s}$ in each condition. $\boldsymbol{E}$, EPSC event times were measured at the peaks (red x's). Current amplitudes were measured as the difference from baseline (green $x ' s$ ) to peak.

including steady-state hair bundle deflection associated with head orientation with respect to gravity. Most spiking cells in the central zone fired rapidly adapting spike trains (Fig. 6A). These cells also had a tall-thin morphology, which may correspond to the central flaskshaped hair cells (Chabbert, 1997). Central flask-shaped hair cells express calretinin (Edmonds et al., 2000) while other hair cells in the central region do not (Heller et al., 2002). Future experiments are needed to investigate the relationships between hair cell physiology, morphology, and calcium buffer expression.

Spiking and nonspiking hair cells appear to have a similar complement of ion channels, but in different ratios. We did not find a larger $I_{\mathrm{Ca}}$ in spiking hair cells (Fig. 5I), but they did have smaller outward currents $\left(I_{\mathrm{BK} \text {,steady }}\right.$ and $\left.I_{\mathrm{KV}}\right)$ that oppose depolarization. Spiking can be induced in nonspiking hair cells by increasing $I_{\mathrm{Ca}}$ (Fig. 7C) or promoted in reluctantly spiking hair cells by blocking $I_{\mathrm{BK}}$ (Fig. 7B) [see also Catacuzzeno et al. (2003b) and Jørgensen and Kroese (2005)]. In addition, the large inward rectifier current $\left(I_{\mathrm{K} 1}\right)$ in spiking hair cells may provide positive feedback that contributes to spiking (Goodman and Art, 1996b).

Our results from the semi-intact preparation differed substantially from previous studies of isolated hair cells (Hudspeth and Lewis, 1988a; Holt and Eatock, 1995; Chabbert, 1997; Catacuzzeno et al., 2003a,b, 2004; Jørgensen and Kroese, 2005). Dissociation with papain has been shown to remove BK channel inactivation, abolish $I_{\mathrm{KV}}$, shift the voltage dependence of $\mathrm{Ca}^{2+}$ channel activation, and increase the frequency and sharpness of electrical tuning in the frog sacculus (Armstrong and Roberts 1998, 2001; Catacuzzeno et al., 2003a), although it does not have this effect in hair cells from the turtle cochlea (Goodman and Art, 1996a). Isolation using bacterial protease VIII preserves $I_{\mathrm{BK} \text {,transient }}$ and $I_{\mathrm{KV}}$ (Catacuzzeno et al., 2003a), but not the spikes and oscillations we observed in current clamp. Spikes occur in the excised frog sacculus (Hudspeth and Corey, 1977; Ashmore, 1983; Armstrong and Roberts, 1998) but not in isolated cells. Spikes are dependent on $\mathrm{Ca}^{2+}$ current through L-type channels (Fig. 7B), which decays in amplitude over the duration of an experiment (data not shown). It is possible that, in addition to direct effects of enzymes on ion channels, the time and handling involved in cell isolation procedures contributes to abolishing spikes. Voltage oscillations and "instabilities" have been reported in hair cells dissociated using bacterial protease VIII (Catacuzzeno et al., 2004) or XXIV (Jørgensen and Kroese, 2005), but these occur at hyperpolarized membrane potentials $(-60$ to $-90 \mathrm{mV})$ and are not expected to evoke release of neurotransmitter.

Experiments with intact preparations are needed to understand how basolateral voltage spikes and oscillations may be interconnected with hair bundle mechanics in vivo. Hair cells possess a feedback mechanism by which changes in membrane potential cause forces to be exerted on the hair bundle. In a frog saccular preparation similar to ours but with MET intact, spontaneous mechanical oscillations of the hair bundle with peak frequencies in the range of $19-46 \mathrm{~Hz}$ were observed in some hair cells (Ramunno-Johnson et al., 2009). Given the reported efficiency of reverse transduction (up to $600 \mathrm{pm} / \mathrm{mV}$ ) (Denk and Webb, 1992), the $50 \mathrm{mV}$ spikes we observed could cause a $30 \mathrm{~nm}$ movement of the hair bundle, sufficient to elicit a large MET current, which is $90 \%$ saturated by a bundle deflection of only 50-120 nm (Hudspeth, 1989). Thus, spikes and voltage oscillations may drive hair bundle oscillations via reverse transduction, potentially exerting forces on the overlying otolithic membrane in vivo. The presence of sensitive bidirectional feedback in vivo presents difficulties for interpreting experimental results from reduced preparations (Lewis, 1988).

The spontaneous electrical and mechanical oscillatory behavior of hair cells may represent the behavior of a high-gain amplifier that operates close to a transition between stability and instability (Eguíluz et al., 2000; Hudspeth et al., 2000; Ospeck et al., 2001). In vivo, adaptation of MET or other feedback processes may hold the 
cell near the transition point (Hopf bifurcation), where amplification is greatest. This interpretation is consistent with our finding that small changes in holding current can cause some hair cells to undergo a transition from stability to oscillatory or spiking activity. We hypothesize that this resulting periodic hair cell activity triggers periodic calcium-dependent neurotransmitter release that determines the timing of background (i.e., spontaneous) spike activity in some frog saccular afferent axons.

\section{References}

Armstrong CE, Roberts WM (1998) Electrical properties of frog saccular hair cells: distortion by enzymatic dissociation. J Neurosci 18:2962-2973.

Armstrong CE, Roberts WM (2001) Rapidly inactivating and non-inactivating calcium-activated potassium currents in frog saccular hair cells. J Physiol 536:49-65.

Ashmore JF (1983) Frequency tuning in a frog vestibular organ. Nature 304:536-538.

Catacuzzeno L, Fioretti B, Perin P, Franciolini F (2003a) Frog saccular hair cells dissociated with protease VIII exhibit inactivating BK currents, KV currents, and low-frequency electrical resonance. Hear Res 175:36-44.

Catacuzzeno L, Fioretti B, Franciolini F (2003b) Voltage-gated outward K currents in frog saccular hair cells. J Neurophysiol 90:3688-3701.

Catacuzzeno L, Fioretti B, Perin P, Franciolini F (2004) Spontaneous lowfrequency voltage oscillations in frog saccular hair cells. J Physiol 561:685-701.

Chabbert CH (1997) Heterogeneity of hair cells in the bullfrog sacculus. Pflugers Arch 435:82-90.

Christensen-Dalsgaard J, Narins PM (1993) Sound and vibration sensitivity of VIIIth nerve fibers in the frogs Leptodactylus albilabris and Rana pipiens pipiens. J Comp Physiol A 172:653-662.

Corey DP, Hudspeth AJ (1983) Kinetics of the receptor current in bullfrog saccular hair cells. J Neurosci 3:962-976.

Crawford AC, Fettiplace R (1980) The frequency selectivity of auditory nerve fibres and hair cells in the cochlea of the turtle. J Physiol 306:79-125.

Crawford AC, Fettiplace R (1981) An electrical tuning mechanism in turtle cochlear hair cells. J Physiol 312:377-412.

Denk W, Webb WW (1992) Forward and reverse transduction at the limit of sensitivity studied by correlating electrical and mechanical fluctuations in frog saccular hair cells. Hear Res 60:89-102.

Díaz ME, Varela-Ramírez A, Serrano EE (1995) Quantity, bundle types, and distribution of hair cells in the sacculus of Xenopus laevis during development. Hear Res 91:33-42.

Eatock RA, Corey DP, Hudspeth AJ (1987) Adaptation of mechanoelectrical transduction in hair cells of the bullfrog's sacculus. J Neurosci 7:2821-2836.

Eatock RA, Saeki M, Hutzler MJ (1993) Electrical resonance of isolated hair cells does not account for acoustic tuning in the free-standing region of the alligator lizard's cochlea. J Neurosci 13:1767-1783.

Edmonds B, Reyes R, Schwaller B, Roberts WM (2000) Calretinin modifies presynaptic calcium signaling in frog saccular hair cells. Nat Neurosci 3:786-790.

Eguíluz VM, Ospeck M, Choe Y, Hudspeth AJ, Magnasco MO (2000) Essential nonlinearities in hearing. Phys Rev Lett 84:5232-5235.

Farris HE, Wells GB, Ricci AJ (2006) Steady-state adaptation of mechanotransduction modulates the resting potential of auditory hair cells, providing an assay for endolymph $\left[\mathrm{Ca}^{+}\right]$. J Neurosci 26:12526-12536.

Fettiplace R, Fuchs PA (1999) Mechanisms of hair cell tuning. Annu Rev Physiol 61:809-834.

Fuchs PA, Evans MG (1988) Voltage oscillations and ionic conductances in hair cells isolated from the alligator cochlea. J Comp Physiol A 164:151-163.

Fuchs PA, Nagai T, Evans MG (1988) Electrical tuning in hair cells isolated from the chick cochlea. J Neurosci 8:2460-2467.

Glowatzki E, Fuchs PA (2002) Transmitter release at the hair cell ribbon synapse. Nat Neurosci 5:147-154.

Goodman MB, Art JJ (1996a) Variations in the ensemble of potassium currents underlying resonance in turtle hair cells. J Physiol 497:395-412.

Goodman MB, Art JJ (1996b) Positive feedback by a potassium-selective inward rectifier enhances tuning in vertebrate hair cells. Biophys J 71:430-442.

Goodman MB, Lockery SR (2000) Pressure polishing: a method for re-shaping patch pipettes during fire polishing. J Neurosci Methods 100:13-15.

Goutman JD, Glowatzki E (2007) Time course and calcium dependence of transmitter release at a single ribbon synapse. Proc Natl Acad Sci U S A 104:16341-16346.

Heller S, Bell AM, Denis CS, Choe Y, Hudspeth AJ (2002) Parvalbumin 3 is an Abundant Ca2+ buffer in hair cells. J Assoc Res Otolaryngol 3:488-498.

Holt JC, Xue J-T, Brichta AM, Goldberg JM (2006) Transmission between type II hair cells and bouton afferents in the turtle posterior crista. J Neurophysiol 95:428-452.

Holt JR, Eatock RA (1995) Inwardly rectifying currents of saccular hair cells from the leopard frog. J Neurophysiol 73:1484-1502.

Holton T, Hudspeth AJ (1986) The transduction channel of hair cells from the bull-frog characterized by noise analysis. J Physiol 375:195-227.

Hossain WA, Antic SD, Yang Y, Rasband MN, Morest DK (2005) Where is the spike generator of the cochlear nerve? Voltage-gated sodium channels in the mouse cochlea. J Neurosci 25:6857-6868.

Hudspeth AJ (1989) How the ear's works work. Nature 341:397-404.

Hudspeth AJ, Corey DP (1977) Sensitivity, polarity, and conductance change in the response of vertebrate hair cells to controlled mechanical stimuli. Proc Natl Acad Sci U S A 74:2407-2411.

Hudspeth AJ, Lewis RS (1988a) Kinetic analysis of voltage- and iondependent conductances in saccular hair cells of the bull-frog, Rana catesbeiana. J Physiol 400:237-274.

Hudspeth AJ, Lewis RS (1988b) A model for electrical resonance and frequency tuning in saccular hair cells of the bull-frog, Rana catesbeiana. J Physiol 400:275-297.

Hudspeth AJ, Choe Y, Mehta AD, Martin P (2000) Putting ion channels to work: mechanoelectrical transduction, adaptation, and amplification by hair cells. Proc Natl Acad Sci U S A 97:11765-11772.

Jørgensen F, Kroese ABA (2005) Ion channel regulation of the dynamical instability of the resting membrane potential in saccular hair cells of the green frog Rana esculenta. Acta Physiol Scand 185:271-290.

Jørgensen F, Ohmori H (1988) Amiloride blocks the mechano-electrical transduction channel of hair cells of the chick. J Physiol 403:577-588.

Keen EC, Hudspeth AJ (2006) Transfer characteristics of the hair cell's afferent synapse. Proc Natl Acad Sci U S A 103:5537-5542.

Koyama H, Lewis ER, Leverenz EL, Baird RA (1982) Acute seismic sensitivity in the bullfrog ear. Brain Res 250:168-172.

Lewis ER (1988) Tuning in the bullfrog ear. Biophys J 53:441-447.

Lewis RS, Hudspeth AJ (1983) Voltage- and ion-dependent conductances in solitary vertebrate hair cells. Nature 304:538-541.

Lewis ER, Narins PM (1985) Do frogs communicate with seismic signals? Science 227:187-189.

Lewis ER, Narins PM, Cortopassi KA, Yamada WM, Poinar EH, Moore SW, Yu X-1 (2001) Do male white-lipped frogs use seismic signals for intraspecific communication? Am Zool 41:1185-1199.

Manley GA (1979) Preferred intervals in the spontaneous activity of primary auditory neurons. Naturwissenschaften 66:582-584.

Martin P, Bozovic D, Choe Y, Hudspeth AJ (2003) Spontaneous oscillation by hair bundles of the bullfrog's sacculus. J Neurosci 23:4533-4548.

Ospeck M, Eguíluz VM, Magnasco MO (2001) Evidence of a Hopf bifurcation in frog hair cells. Biophys J 80:2597-2607.

Ramunno-Johnson D, Strimbu CE, Fredrickson L, Arisaka K, Bozovic D (2009) Distribution of frequencies of spontaneous oscillations in hair cells of the bullfrog sacculus. Biophys J 96:1159-1168.

Rasband MN, Peles E, Trimmer JS, Levinson SR, Lux SE, Shrager P (1999) Dependence of nodal sodium channel clustering on paranodal axoglial contact in the developing CNS. J Neurosci 19:7516-7528.

Roberts WM, Rutherford MA (2008) Linear and nonlinear processing in hair cells. J Exp Biol 211:1775-1780.

Rutherford MA, Roberts WM (2006) Frequency selectivity of synaptic exocytosis in frog saccular hair cells. Proc Natl Acad Sci U S A 103:2898-2903.

Shepherd GM, Corey DP (1994) The extent of adaptation in bullfrog saccular hair cells. J Neurosci 14:6217-6229.

Steinacker A, Romero A (1992) Voltage-gated potassium current and resonance in the toadfish saccular hair cell. Brain Res 574:229-236.

Sugihara I, Furukawa T (1989) Morphological and functional aspects of two different types of hair cells in the goldfish sacculus. J Neurophysiol 62:1330-1343.

Vollrath MA, Eatock RA (2003) Time course and extent of mechanotransducer adaptation in mouse utricular hair cells: comparison with frog saccular hair cells. J Neurophysiol 90:2676-2689.

Yu XL, Lewis ER, Feld D (1991) Seismic and auditory tuning curves from bullfrog saccular and amphibian papillar axons. J Comp Physiol A 169:241-248. 